\title{
Reuniting the Ötztal Nappe: the tectonic evolution of the Schneeberg Complex
}

\author{
Linus Klug ${ }^{1}$ Nikolaus Froitzheim ${ }^{1}$
}

Received: 7 December 2020 / Accepted: 28 October 2021 / Published online: 27 November 2021

(c) The Author(s) 2021

\begin{abstract}
The Ötztal Nappe in the Eastern Alps is a thrust sheet of Variscan metamorphic basement rocks and their Mesozoic sediment cover. It has been argued that the main part of the Ötztal Nappe and its southeastern part, the Texel Complex, belong to two different Austroalpine nappe systems and are separated by a major tectonic contact. Different locations have been proposed for this boundary. We use microprobe mapping of garnet and structural field geology to test the hypothesis of such a tectonic separation. The Pre-Mesozoic rocks in the area include several lithotectonic units: Ötztal Complex s.str., Texel Complex, Laas Complex, Schneeberg Complex, and Schneeberg Frame Zone. With the exception of the Schneeberg Complex which contains only single-phased (Eoalpine, i.e. Late Cretaceous) garnet, all these units have two-phased garnet with Variscan cores and Eoalpine rims. The Schneeberg Complex represents Paleozoic sediments with only low-grade (sub-garnet-grade) Variscan metamorphism which was thrust over the other units and their Mesozoic cover (Brenner Mesozoic) during an early stage of the Eoalpine orogeny, before the peak of Eoalpine metamorphism and garnet growth. Folding of the thrust later modified the structural setting so that the Schneeberg Thrust was locally inverted and the Schneeberg Complex came to lie under the Ötztal Complex s.str. The hypothesized Ötztal/Texel boundaries of earlier authors either cut across undisturbed lithological layering or are unsupported by any structural evidence. Our results support the existence of one coherent Ötztal Nappe, including the Texel Complex, and showing a southeastward increase of Eoalpine metamorphism which resulted from southeastward subduction.
\end{abstract}

Keywords Eastern Alps $\cdot$ Austroalpine basement $\cdot$ Garnet $\cdot$ Eo-Alpine orogeny $\cdot$ Ötztal Nappe $\cdot$ Schneeberg Complex

\section{Introduction}

Deeply subducted and exhumed rocks are of special value for understanding the geodynamics of collisional orogeny, in our case the Eoalpine Orogeny in the Eastern Alps, which peaked in the Late Cretaceous. The Texelgruppe in the southeastern Ötztal Alps bears the westernmost eclogites of the Eoalpine high-pressure belt (Hoinkes et al. 1991; Poli 1991; Sölva et al. 2001; Habler et al. 2006; Bargossi et al. 2010; Zanchetta et al. 2013) (Fig. 1). Correlating Austroalpine tectonic units with their paleogeographic origin and geodynamic position in the Eoalpine Orogeny is necessary for a valid tectonic synthesis. In the case of the southeastern Ötztal Alps, such correlation is still controversial. Schmid

Linus Klug

klug@uni-bonn.de

1 Institute of Geosciences, University of Bonn, Meckenheimer Allee 169, 53115 Bonn, Germany et al. (2004) divided the Ötztal Nappe, formerly interpreted as one tectonic unit (e.g. Schmidegg 1964), into two units belonging to two different of their five Austroalpine nappe systems (Ötztal-Bundschuh Nappe System and KoralpeWölz Nappe System). It was suggested that the Ötztal Complex s.str. (Ötztal-Bundschuh Nappe System) and the Texel Complex (Koralpe-Wölz Nappe System) are separated by the Schneeberg Normal Fault Zone (Sölva et al. 2005).

In addition to the Ötztal s.str. and Texel complexes, a third tectonic complex is often distinguished along the border of the two: the Schneeberg Complex (e.g. Sölva et al. 2005). This complex is a key feature of the regional geology, characterized by the absence of Variscan garnet (De Pieri and Galetti 1972; Zanettin and Justin-Visentin 1980; Sölva et al. 2005). Pedevilla and Tropper (2012) performed element mapping of garnets to localize the change from singlephased (Eoalpine) garnets of the Schneeberg Complex to the two-phased (Variscan and Eoalpine) garnets of the Ötztal Complex s.str. along the Timmelsjoch road. Using this 


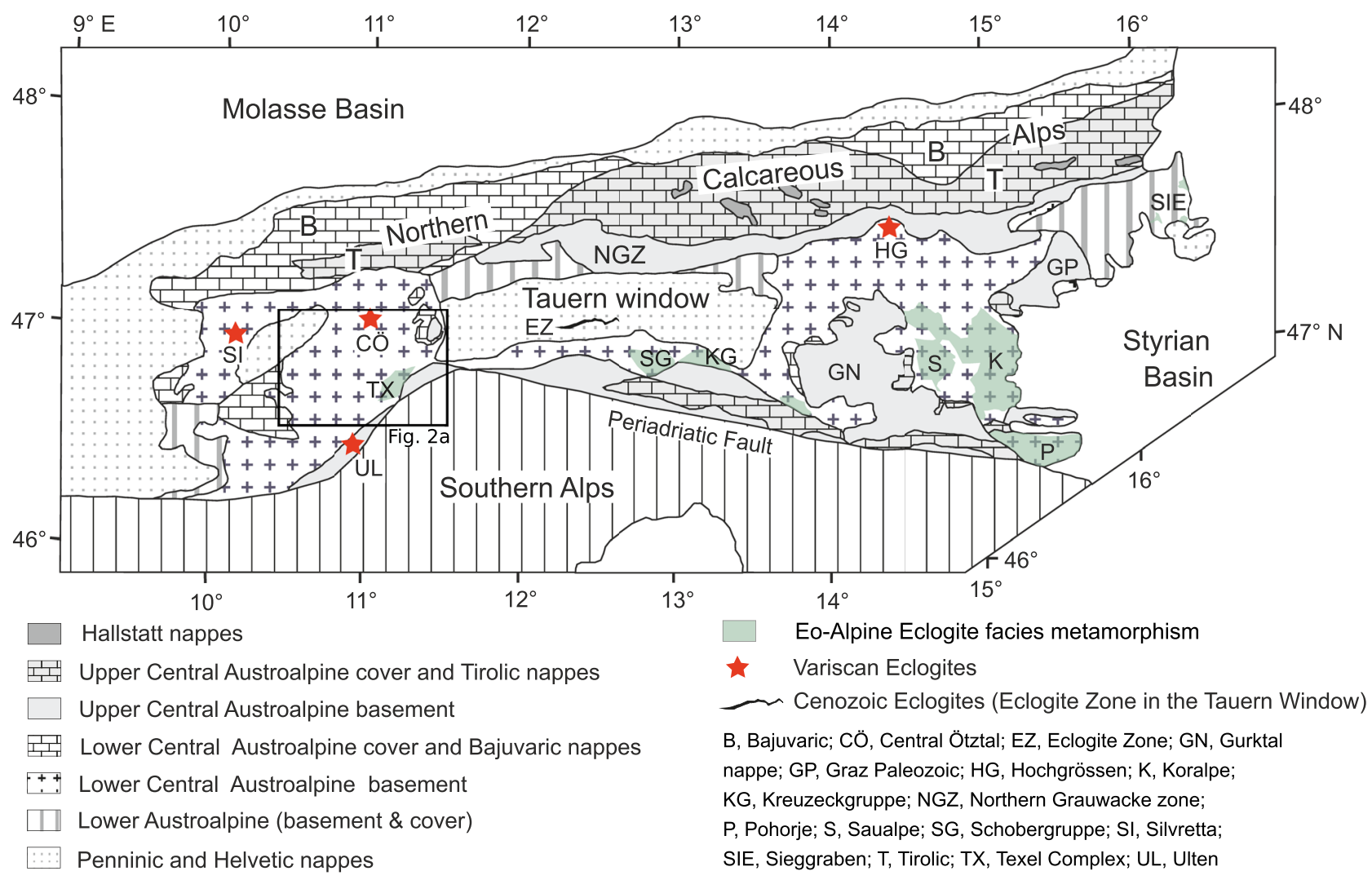

Fig. 1 Tectonic map of the Eastern Alps with the main units of the Eoalpine nappe stack and locations of Variscan, Eoalpine and Cenozoic eclogite (after Hauke et al. 2019)

criterion, they were able to draw a sharp border in outcrop scale between the Ötztal Complex s.str. and the Schneeberg Complex. Two-phased, Variscan, and Eoalpine garnets occur also in the Texel Complex (e.g. Miladinova 2019).

In order to test the hypothesis of a tectonic separation between Ötztal s.str. and Texel complexes, we studied the structural setting and the garnet composition in the entire Ötztal-Texel boundary zone, including the Schneeberg Complex, and reconstructed the tectonic evolution of the area.

This has major implications for the regional geodynamic interpretation.

\section{Regional geologic background}

In the Southeast of the Ötztal and Stubai Alps, an area of (garnet-)mica schists with calcschists and amphibolites stands out of the surrounding basement of pre-Mesozoic gneisses and their Mesozoic cover (Figs. 1 and 2). This area is known as the Schneeberg Complex, Schneeberg unit or Schneeberger Zug since unpublished geological manuscript maps of the nineteenth century (Sander 1920; Hofmann and Cernajsek 1993). The name is associated with the famous mining area at St. Martin am Schneeberg (Mair et al. 2007), although its ore deposits are limited to the surrounding gneisses. Many studies have dealt with the tectonics and metamorphism of the Schneeberg Complex and its relations to the surrounding units (e.g. Sander 1920, 1929; Schmidegg 1932, 1964; Schmidt 1965; Baggio et al. 1971; Zanettin 1971; Zanettin and Justin-Visentin 1971, 1980; Satir 1976; Helbig and Schmidt 1978; Mauracher 1980; Tessadri 1981; Hoinkes 1981, 1983; Frank et al. 1987; Hoinkes et al. 1987; Purtscheller et al. 1987a, b; Thöni and Hoinkes 1987; van Gool et al. 1987; Gregnanin et al. 1995; Gregnanin and Valle 1995; Konzett and Hoinkes 1996; Sölva et al. 2005; Zanchetta 2010; Krenn et al. 2011; Pedevilla and Tropper 2012; Pomella et al. 2016). South of the Schneeberg Complex a band of marbles and mica schists is called the Laas Series, due to its similarities to the marbles near Laas in the upper Vinschgau, belonging to the Campo Nappe. The Laas Series is sometimes referred to as part of the Schneeberg Complex, or both are collectively termed Schneeberg-Laas-Series. A detailed map of the various units was provided by Mauracher (1980). This includes the distinction between the "Schneeberg Synclines" and the "Schneeberg Frame Zone" of basement-like mica-schists. We will use the term "Schneeberg Complex" in our nomenclature instead of the term "Schneeberg synclines" of Mauracher (1980) to avoid confusion 
Fig. 2 a Tectonic map of the southern Ötztal Nappe with rough thermal isograds of the Eoalpine metamorphism. $B$ Braulio basement, $M$ Marlengo Slice, $T$ Tonale unit, VSZ Vinschgau Shear Zone. Detail (b) of the southeastern Ötztal Nappe. Detail (c) of St. Martin am Schneeberg area. Detail (d) of Telfer Weißen/Rosskopf/ Schleyerberg area. Mod. after Mauracher (1980), Frank et al. (1987), Schmid and Haas (1989), Froitzheim et al. (1997), Elias (1998), Fügenschuh et al. (2000), Frizzo (2002), Schuster (2003), Bargossi et al. (2010), Rockenschaub and Nowotny (2011), Bousquet et al. (2012)
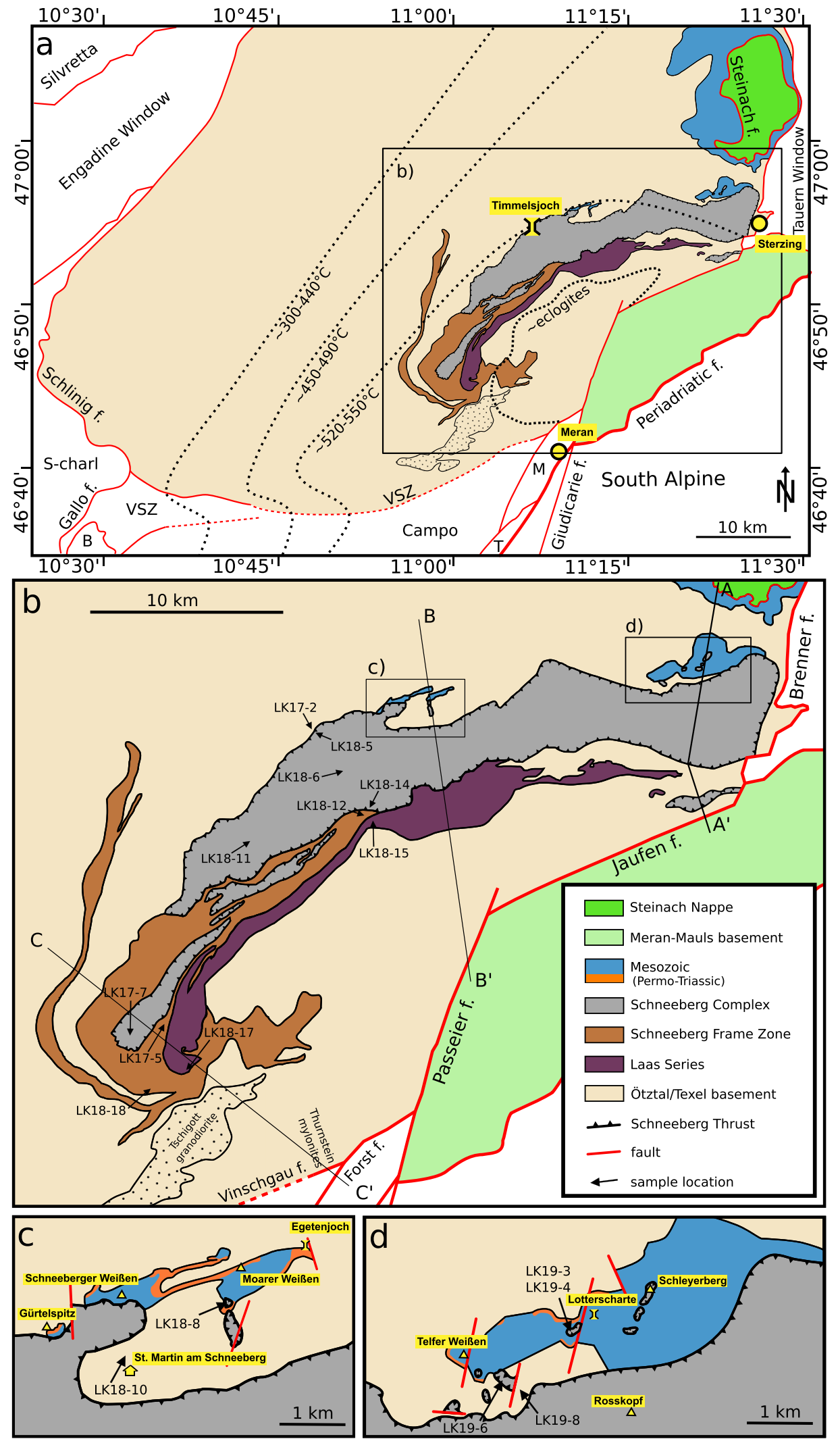
with structural terms. The Schneeberg Frame Zone (Mauracher 1980) is analogous to the "Hochwart Serie" of Zanettin and Justin-Visentin (1971) and the "Umhüllende Glimmerschiefer" of Helbig and Schmidt (1978) (Hoinkes et al. 1987). We will show that the Schneeberg Frame Zone is part of the Variscan basement. It is not clear how far into the Ötztal Complex s.str. and the Texel Complex the mica schists of the Schneeberg Frame Zone extend. We adopted the boundaries between gneisses and mica schists as mapped by Mauracher (1980). If we had used the boundaries mapped by Bargossi et al. (2010), the Schneeberg Frame Zone would occupy a slightly larger area. Further, we will show that the Laas Series is distinct from the Schneeberg Complex. South of the Schneeberg Complex the unit of basement gneisses of the Texelgruppe is called Texel Complex. Since the terms Ötztal basement or Ötztal Complex can be and have been used for the surrounding gneisses northwest and southeast of the Schneeberg Complex, we use Ötztal Complex s.str. for the basement northwest of the Schneeberg Complex. Basement in this context means rocks with a Variscan mediumto high-grade metamorphic imprint. The basement consists mainly of paragneisses with minor orthogneiss, mica schist, and amphibolite. The Tschigott Granodiorite stands out as the largest orthogneiss body and a lithological marker inside the basement.

The Brenner Mesozoic is the sedimentary cover of the Ötztal basement, resting with an erosional unconformity on the basement. The clastic Verrucano (Permo-Triassic) at the base is followed by Triassic and Jurassic carbonates (Kübler and Müller, 1962). The Brenner Mesozoic shows Eoalpine metamorphism (Dietrich 1983).

We will show that all these units belong to the Ötztal Nappe and therefore will use the term Ötztal Nappe collectively for the Ötztal Complex s.str., the Brenner Mesozoic, the Schneeberg Frame Zone, the Schneeberg Complex, the Laas Series, and the Texel Complex. The Ötztal Nappe has an Eoalpine metamorphic gradient from sub-greenschist facies in the Northwest to eclogite facies in the Southeast (e.g. Frank et al. 1987; Elias 1998; Schuster 2003; Schmid et al. 2004; Habler et al. 2006; Bousquet et al. 2012).

The Schneeberg Thrust (Gregnanin and Valle 1995) and the Schneeberg Normal Fault Zone (Sölva et al. 2005) play important roles in the interpretation of the tectonic relations in the study area. The first originated in the thrusting of the Schneeberg Complex over the Ötztal basement and the Brenner Mesozoics. Between the Schneeberg Complex and the Texel basement in the South, Gregnanin et al. (1995) mentioned the Zermaid thrust as the basal contact of the Schneeberg Complex. We will call this contact separating the Schneeberg Complex from the Ötztal/Texel basement and the Brenner Mesozoics "Schneeberg Thrust" on all sides. Sölva et al. (2005) introduced the ductile Schneeberg Normal Fault Zone, comprising the entire Schneeberg Complex and parts of the adjacent units, as a tectonic element between the Ötztal Complex s.str. and the Texel Complex. They interpreted the Schneeberg Normal Fault Zone as a northwest-dipping ductile normal fault. Pomella et al. (2016), in contrast, interpreted that this shear zone is only apparently a normal fault and in reality represents an originally southeast-dipping contact.

The Ötztal Nappe is bordered in the South by the Eoalpine Vinschgau Shear Zone (VSZ) which accommodated westward thrusting of the Ötztal Nappe over the Campo Complex (Schmid and Haas 1989). The VSZ disappears to the east under the Vinschgau valley deposits. Close to Meran a small segment of the border between the Ötztal Nappe and the Campo Complex appears again at the surface, known as the Thurnstein Mylonites (Bargossi et al. 2010). Both shear zones dip shallowly N to NNW and show subhorizontal E-W lineation and top-to-W shear sense. The VSZ is cut off in the West by the Schlinig and Gallo lines. These Late Cretaceous, top-SE to -ESE normal faults border the Ötztal and Campo nappes against the S-charl Nappe (Froitzheim et al. 1997). The Thurnstein Mylonites are cut off in the East by the Forst Line. The latter forms the border between the Marlengo Slice to the East and the Ötztal Nappe and Campo Complex to the West (Bargossi et al. 2010). The Passeier Fault dips steeply WNW as a sinistral oblique thrust of the Ötztal Nappe over the Meran-Mauls Basement. The Forst and Passeier faults belong to the Giudicarie Fault System and are related to Miocene indentation (Viola et al. 2001; Pomella et al. 2012). Further north the Ötztal and MeranMauls units are separated by the NW-dipping Jaufen Fault (Spiess 1995), which acted as a Miocene, top-to-NW normal fault (Pomella et al. 2012) after Late Cretaceous, top-toSE normal faulting and rotation (Viola et al. 2001; Pomella et al. 2016). The W-dipping Brenner Normal Fault System, activated by the Miocene Tauern Window doming and E-W crustal extension, separates the Ötztal Nappe from the Lower Austroalpine and Penninic nappes in the East (Selverstone 1988; Behrmann 1988; Fügenschuh et al. 2000; Rockenschaub and Nowotny 2011; Klotz et al. 2019).

On top of the Ötztal basement and the Brenner Mesozoics lies the Steinach Nappe. It shows only anchizonal metamorphism (Eoalpine) and was juxtaposed to the lower units by Late Cretaceous, ESE-directed normal faulting (Fügenschuh et al. 2000). An important low-angle normal fault with a belt of ductile mylonites in the footwall lies at the base of the Steinach Nappe. In the following, we will use the name "Steinach Normal Fault" for this extensional detachment.

\section{Methods}

We compiled unit boundaries using the following geological maps: sheet Passo di Resiá, 1:100,000 (ISPRA 1925; Hammer 1926); sheet Monte Cevedale, 1:100.00 
(ISPRA 1951); sheet Bolzano, 1:100,000 (ISPRA 1957), sheet Sölden \& St. Leonhard, 1:75,000 (Schmidegg 1932); sheet Meran, 1:100,000 (ISPRA 1970; Baggio et al. 1971); sheet Meran, 1:50,000 (Bargossi et al. 2010); sheet Sterzing, 1:50,000 (Rockenschaub and Nowotny 2011), Mauracher (1980), Frizzo (2002), and GeoBrowser (Autonomous Province Bolzano - South Tyrol (2021). Mauracher (1980) covered the complete Schneeberg Complex, while the map of Frizzo (2002) covered the area from St. Martin am Schneeberg to the Telfer Weißen in more detail on a smaller scale. During field work, we studied the structural relations in several key areas of the Schneeberg Complex. Based on these, we constructed several simplified cross sections. We used the compiled map to sample rocks from all the relevant units for garnet element mapping.

We present samples from strategic locations in and around the Schneeberg Complex (Fig. 2). Reassessment of structures in the field including rocks of the Ötztal Complex s.str., the Brenner Mesozoic, and the Schneeberg Complex at Gürtelspitz (Schneeberg area) and at Lotterscharte (Telfer Weißen/Rosskopf/Schleyerberg area) is included in the discussion.

Samples were cut with a rock saw and representative garnet-bearing sections were chosen for thin-section preparation. In sets of uniform garnets the largest mineral cross sections were chosen for element mapping to minimize the chance of a lateral cut and of missing the grain center.

We prepared element distribution maps on a JEOL Superprobe JXA 8200 at the Institute of Geosciences, University of Bonn. Maps for Fe, $\mathrm{Ca}, \mathrm{Mg}$, and $\mathrm{Mn}$ were obtained in WDS mode employing a beam current of 80
$\mathrm{nA}$ and an acceleration voltage of $15 \mathrm{kV}$. Measuring times were 100-150 ms.

\section{Results}

\section{Garnet element mapping}

The mapped garnets can be divided in two groups by their element distribution patterns. These are single- and twophased garnets. The phases are garnet growth phases. In Table 1 the investigated samples are listed with garnet phase numbers, rock type, GPS coordinates, and unit affiliation after Mauracher (1980) and Frizzo (2002). In Fig. 2 sample locations are depicted on a tectonic map.

The samples LK18-11 and LK19-8 are included in the results, even though problems in measurement consistency occurred. Measured intensities increase in scanning direction from left to right suddenly for LK18-11 and gradually for LK19-8. This is best visible in the Fe maps (Figs. 3 and 4). In both samples the relevant observation of garnet growth phases is still possible.

\section{Single-phased garnets}

We found single-phased garnets in the samples LK17-7, LK18-5, LK18-6, LK18-8, LK18-11, LK18-14, LK19-3, LK19-4, and LK19-6 (Fig. 3). "Single-phased" refers to continuous garnet growth. This usually includes compositional zoning resulting from changes in conditions, like temperature, pressure, fluid composition, and element availability, during the growth.
Table 1 Sample list with coordinates in UTM WGS84 $\mathrm{Z}: 32 \mathrm{~T}$

\begin{tabular}{llllll}
\hline Sample & $\begin{array}{l}\text { Garnet } \\
\text { Phases }\end{array}$ & Rock Type & Unit & N & E \\
\hline LK17-2 & 2 & Paragneiss & Ötztal Complex s.str. & 661549 & 5195532 \\
LK17-5 & 2 & Quarzite & Schneeberg Frame Zone & 654763 & 5180021 \\
LK17-7 & 1 & Micaschist & Schneeberg Complex & 653115 & 5179419 \\
LK18-5 & 1 & Amphibolite & Schneeberg Complex & 661582 & 5195425 \\
LK18-6 & 1 & Micaschist & Schneeberg Complex & 664245 & 5193918 \\
LK18-10 & 2 & Paragneiss & Ötztal Complex s.str. & 665817 & 5196261 \\
LK18-11 & 1 & Amphibolite & Schneeberg Complex & 659256 & 5190645 \\
LK18-12 & 2 & Micaschist & Schneeberg Frame Zone & 664125 & 5191359 \\
LK18-14 & 1 & Micaschist & Schneeberg Complex & 664312 & 5191600 \\
Lk18-15 & 2 & Micaschist & Laas Series & 664827 & 5191046 \\
LK18-17 & 2 & Micaschist & Laas Series & 655855 & 5177588 \\
LK18-18 & 2 & Micaschist & Schneeberg Frame Zone & 654372 & 5176644 \\
LK19-3 & 1 & Micaschist & Schneeberg Complex & 680608 & 5199602 \\
LK19-4 & 1 & Micaschist & Schneeberg Complex & 680608 & 5199602 \\
LK19-6 & 1 & Micaschist & Schneeberg Complex & 679617 & 5198905 \\
LK19-8 & 2 & Paragneiss & Ötztal Complex s.str. & 679987 & 5198724 \\
\hline
\end{tabular}


Fig. 3 Element distribution maps of single-phased garnets. All samples are from the Schneeberg Complex

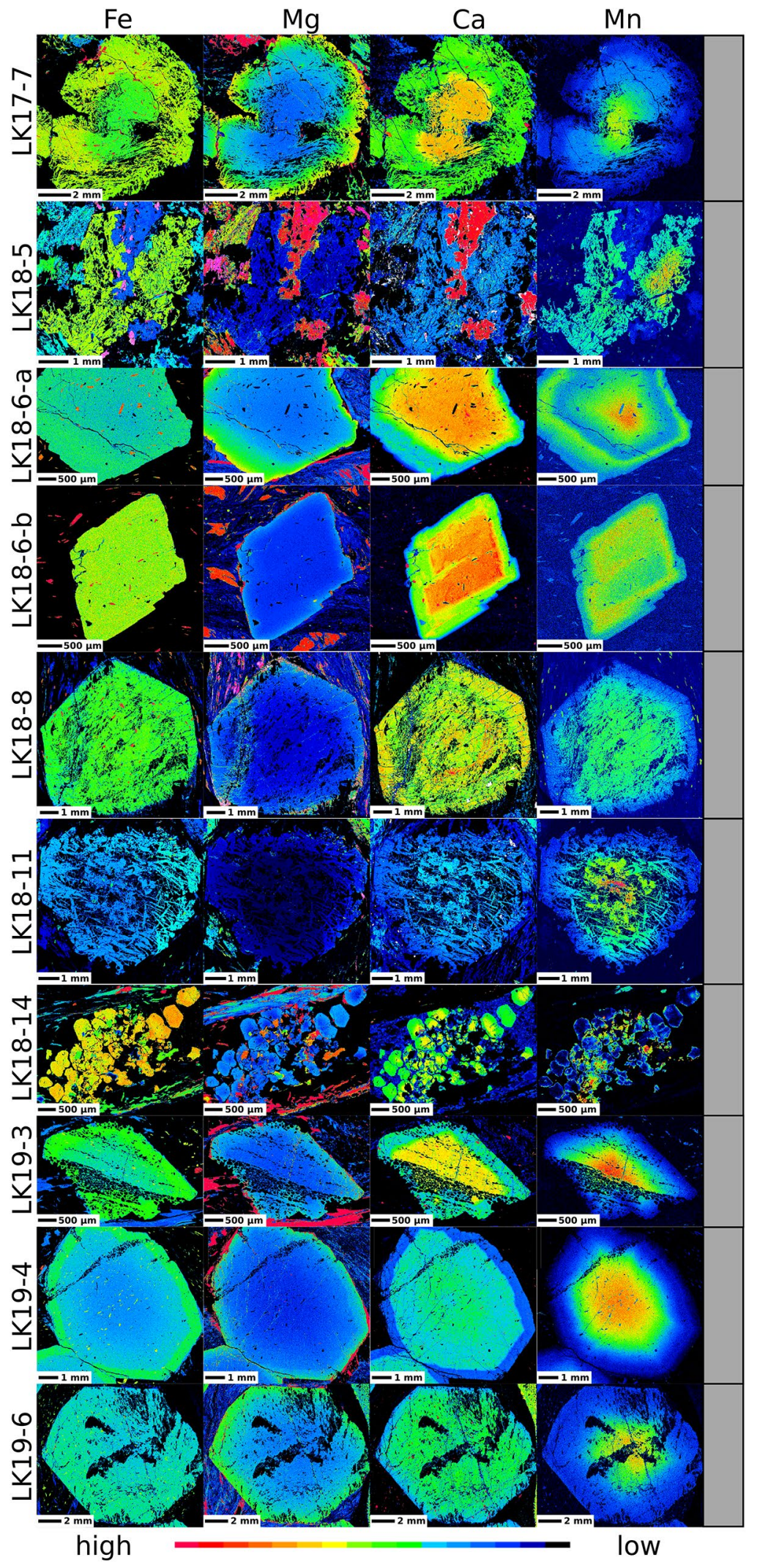




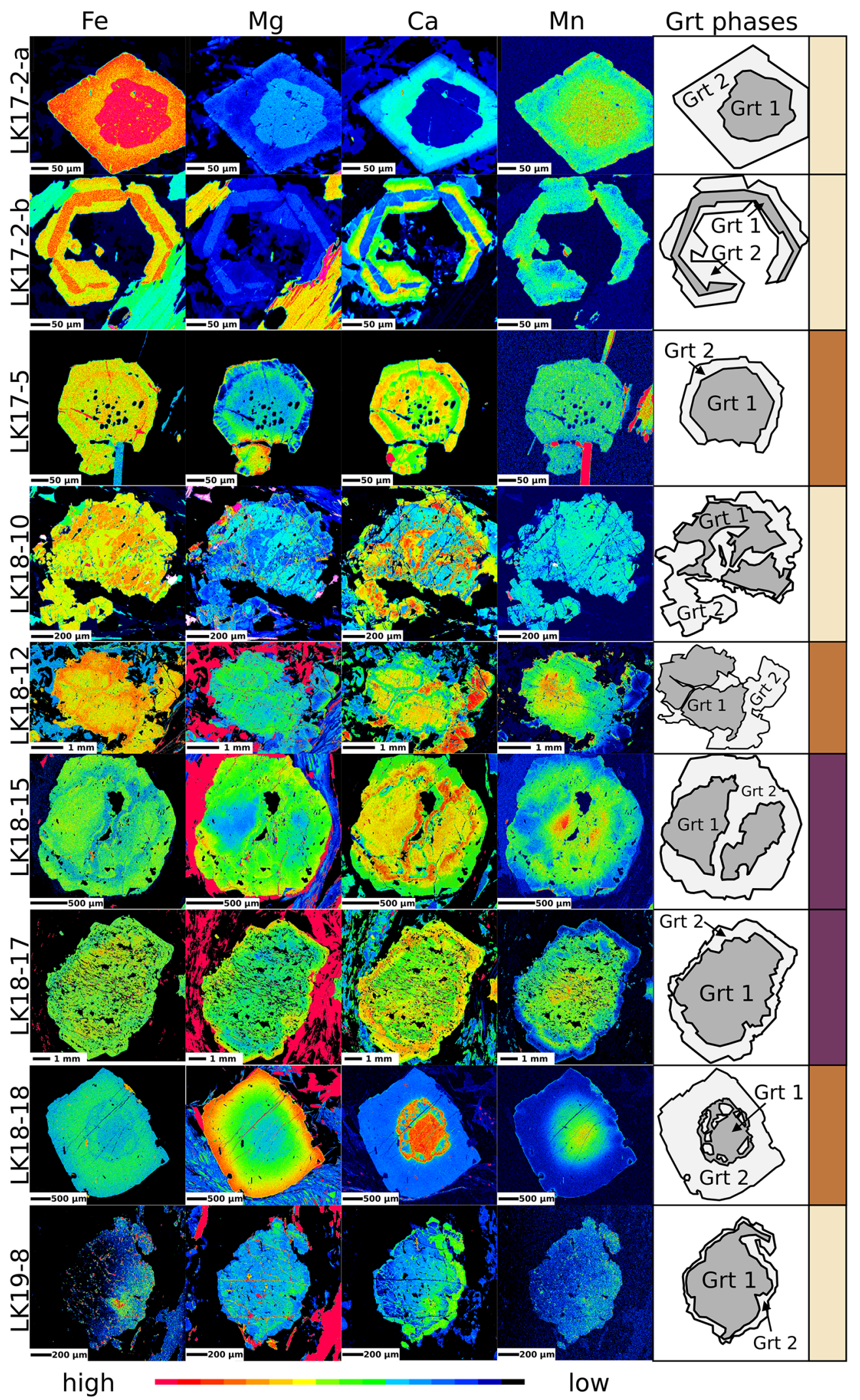

Fig. 4 Element distribution maps of two-phased garnets. The phase boundaries are redrawn in a sketch (Grt $1=$ Variscan; Grt $2=$ Eoalpine). The last column shows the unit affiliation coloured as in Fig. 1 
In garnets of sample LK18-8 oscillatory growth zoning is visible in the $\mathrm{Ca}$ distribution by multiple increases and decreases of $\mathrm{Ca}$ from the core to the rim, while the euhedral shape of these zones is constant. These zones are not resolved in the other elements, where only one decrease $(\mathrm{Mn})$, one increase $(\mathrm{Mg})$, or no change $(\mathrm{Fe})$ is visible. In the two maps of sample LK18-6-a and b, oscillatory garnet growth is visible in Mn zoning by an initial decrease from the core, an intermittent increase, and a final decrease to the rim. The growth zoning of $\mathrm{Ca}$ shows a stepwise decrease. As the compositional zoning of $\mathrm{Ca}$ and $\mathrm{Mn}$ is parallel to the shape of the garnet crystals and without a growth hiatus, we categorize these garnets as single phased. Despite the otherwise euhedral zoning of LK18-6b, on one side the core has a gap filled with garnet of a Ca content like that of the outer zones. This could hint to a crack healed during growth.

Abundant inclusions in single-phased garnets show a static overgrowth of host rocks fabric. Foliation (e.g. LK193, LK19-4), mild and strong folding (e.g. LK17-7, LK196), or coarse mineral textures (e.g. LK18-5, LK18-11) are preserved by quartz inclusions. Quartz-inclusion-rich or -poor zones in the garnets originate from quartz- and micarich layers in the host rock, respectively. In some samples (LK18-5, LK18-8, LK18-11, LK19-3, LK19-6) poikiloblastic or honeycomb forms (c.f. Hawkins et al. 2007) occur in the quartz-inclusion-rich zones in garnets. All investigated samples with single-phased garnets are from rocks of the Schneeberg Complex.

\section{Two-phased garnets}

We found two-phased garnets in the samples LK17-2, LK17-5, LK18-10, LK18-12, LK18-15, LK18-17, LK18-18, and LK19-8 (Fig. 4). In contrast to single-phased garnets, two-phased garnets show a distinct unconformity in their zonation. This separates the garnet into an older core and a younger rim. The geometry of the cores varies strongly due to inter-phase resorption processes. Second-phase garnet growth starts on the core boundaries and is dependent on the core geometry. The element distribution in garnet cores can be uniform (i.e. equilibrated, e.g. LK17-2, LK18-18) or with an original zonation (e.g. LK17-5, LK18-10, LK18-12, LK18-17). In sample LK17-2 garnets preserved an atollshaped core with second-phase garnet growth on the inner and outer side of the core. Patterns of a similar process are visible in the other garnets, where smaller holes, original inclusions, or fractures are filled with second-phase garnet (LK17-2, LK18-10, LK18-12, LK18-15, LK18-17, LK1818, LK19-8). LK17-5 is a metasandstone. Therefore, a detrital origin of the preserved garnet core cannot be excluded, as the size of the garnet core (ca. $0.3 \mathrm{~mm}$ ) is within the range of the possible sediment grain size (c.f. Manzotti and Ballèvre 2013).
In none of the samples from the Schneeberg Complex two-phased garnets were observed. In the Ötztal Complex s.str., the Schneeberg Frame Zone, and the Laas Series, only two-phased garnets were observed.

\section{Discussion}

\section{Garnet growth phases}

The Ötztal Complex s.str. experienced a medium- to highgrade Variscan metamorphism prior to the Eoalpine metamorphism: Garnet growth is reported in two phases of Variscan and Eoalpine age, with increasing Eoalpine proportion from northwest to southeast, consistent with the increasing Eoalpine metamorphic grade (e.g. Frank et al. 1987; Purtscheller et al. 1987b; Miller and Thöni 1995).

Hoinkes et al. (1991) and Sölva et al. (2001) presented two-phased garnets in eclogites and metapelites, respectively, from the Texel Complex. Habler et al. (2006) found two-phased garnet in tonalitic orthogneiss and metapelite from the Texel Complex and suggested a pre-Alpine age for the cores based on $\mathrm{Sm}-\mathrm{Nd}$ data. In eclogites from the same area, they also found complex garnet growth and resorption but suggested that these features formed during a single, Eoalpine metamorphic cycle for which they determined a Cretaceous age ( $85 \pm 5 \mathrm{Ma}$ ) using $\mathrm{Sm}-\mathrm{Nd}$ geochronology. $\mathrm{Lu}-\mathrm{Hf}$ dating of two-phased garnets from eclogites of the Texel Complex by Miladinova (2019) resulted in a "Triassic" age, interpreted to result from the mixture of Variscan and Eoalpine garnet domains. Hauke et al. (2019) succeeded in dating both Variscan and Eoalpine metamorphism in eclogites with similar two-phased garnet further east in the Eoalpine high-pressure belt (Schobergruppe), also using Lu-Hf.

Therefore, we consider the two-phased garnets presented here to be Variscan in the cores and Eoalpine in the rims. An exception is sample LK17-5, where a detrital origin of the garnet core cannot be excluded due to the psammitic nature of the protolith. High garnet abundance and garnet sizes in metapelitic rocks speak against a detrital origin of garnet cores in the other samples.

The single-phased garnets of the Schneeberg Complex are of Eoalpine age and without a Variscan precursor (Sölva et al. 2005). The samples LK17-2 and LK18-5 are from the area also studied by Pedevilla and Tropper (2012) and the observed garnet phases are consistent with their results. The two-phased garnets of the samples LK18-12 and LK18-18 show that the Schneeberg Frame Zone is not only "basement-like", as described by Mauracher (1980), but indeed part of the basement. Two-phased garnets of the Frame Zone were already described by Hoinkes et al. (1987). Basement in this context is defined as rocks with a Variscan 
medium- to high-grade metamorphic imprint. From north to south, the following units are part of the basement, due to the occurrence of two-phased garnets: Ötztal Complex s.str., Schneeberg Frame Zone, Laas Series, and Texel Complex.

Units without a high-grade Variscan imprint are the Brenner Mesozoic and the Schneeberg Complex. For the Brenner Mesozoic, a sedimentary contact to the basement (erosional unconformity) is clear and well preserved. The Schneeberg Complex does not resemble any of the members of the Brenner Mesozoic and is therefore interpreted as a Paleozoic sediment series with no or only low-grade ("sub-garnet-grade") Variscan metamorphism. Unpublished detrital zircon ages from the Schneeberg Complex support a Paleozoic deposition age (Klug et al., in prep.). Furthermore, structural investigations of Gregnanin et al. (1995) and Gregnanin and Valle (1995) report Variscan deformation structures (D1-D2) in the Schneeberg Complex predating the Brenner Mesozoic sediments and the Eoalpine deformation (D3). The fabrics overgrown by Eoalpine garnet are of Variscan age.

This division of structural units is partly compatible with Krenn et al. (2011), although these authors considered a sedimentary deposition of the Schneeberg Complex on the basement units. Krenn et al. (2011) interpreted the Laas Series and the Schneeberg Frame Zone after Mauracher (1980) as part of the Texel Complex (basement). Although Helbig and Schmidt (1978) and Mauracher (1980) described the "basement-like" character of the Schneeberg Frame Zone ("Umhüllende Glimmerschiefer"), they regarded it as part of the Schneeberg units because it forms an envelope around the Schneeberg Complex.

Chemical composition data of garnet from the Ötztal Complex s.str. (e.g. Hoinkes 1981; Purtscheller et al. 1987b; Schmid and Haas 1989; Gregnanin et al. 1995; Miller and Thöni 1995; Rode et al. 2012; Holzmann and Tropper 2013; Schulz et al. 2019), the Texel Complex (e.g. Zanettin and Justin-Visentin 1980; Hoinkes et al. 1991; Poli 1991; Spalla 1993; Sölva et al. 2001; Habler et al. 2006; Schneider 2013; Zanchetta et al. 2013; Miladinova 2019), the Schneeberg Complex (e.g. Hoinkes 1978, 1981, 1983; Zanettin and Justin-Visentin 1980; Konzett and Hoinkes 1996), the Schneeberg Frame Zone (e.g. Hoinkes 1978, 1981), and the Brenner Mesozoic (Gregnanin and Valle 1995) are abundant in the literature. The almandine (Alm) content dominates in all garnets, while the pyrope (Prp), grossular (Grs), and spessartine (Sps) contents vary strongly. The compositions vary slightly between the Ötztal Complex s.str. $\left(\mathrm{Alm}_{61-82} \operatorname{Prp}_{3-20} \mathrm{Grs}_{3-23} \mathrm{Sps}_{0.3-14}\right.$; wt\%: 17-35 FeO, 1-13 MgO, 2-11 CaO, 0.3-10 MnO), the Texel Complex $\left(\mathrm{Alm}_{52-82} \operatorname{Prp}_{7-20} \mathrm{Grs}_{5-35} \mathrm{Sps}_{0.1-9}\right.$; wt $\%: 23-44 \mathrm{FeO}, 0,3-10$ $\mathrm{MgO}, 0,5-13 \mathrm{CaO}, 0.1-15 \mathrm{MnO}$ ), the Schneeberg Complex $\left(\mathrm{Alm}_{54-66} \operatorname{Prp}_{12-17} \mathrm{Grs}_{15-28} \mathrm{Sps}_{3-7}\right.$; wt \%: 22-46 FeO, 1-7 $\mathrm{MgO}$, 4-15 CaO, 0-7 MnO), the Schneeberg Frame Zone (wt\%: 28-40 $\mathrm{FeO}, 1-5 \mathrm{MgO}, 1-9 \mathrm{CaO}, 0.1-5 \mathrm{MnO}$ ), and the
Brenner Mesozoic (wt\%: 33-35 FeO, $2 \mathrm{MgO}, 3-4 \mathrm{CaO}, 1-3$ $\mathrm{MnO}$ ). The composition changes of the single or multi-phase zonations are diverse. The Sps content is higher in the cores. The Alm and Prp contents change mostly in the opposite direction with respect to the Grs content. In single-phased garnets (Schneeberg Complex) Alm and Prp decrease and Grs increases from core to rim. The change direction is irregular in multi-phased garnets. For our interpretation the garnet composition is less important than the existence of a phase transition observable by element mapping.

\section{Structural relations}

The existence of the early Eoalpine Schneeberg Thrust over the Brenner Mesozoics in the eastern part of the Schneeberg Complex is documented in great detail by Gregnanin and Valle (1995). Investigated garnets in the Telfer Weißen area and the St. Martin am Schneeberg area support this structural observation.

Along the ridges from Telfer Weißen to Schleyerberg and to Rosskopf, several slivers of garnet-bearing phyllitic mica-schists overlie the Ötztal basement and also its Mesozoic cover (Fig. 2d). At Lotterscharte and on Schleyerberg they overlie the Wetterstein Dolomite (Ladinium) and the Hauptdolomit (Norium), respectively. The garnets in the mica schists are single phased and several millimeters up to one centimeter in size (LK19-3 and LK19-4 in Fig. 3). These are typical for the rocks of the Schneeberg Complex. The interpretation of these slivers as part of the anchizonal Steinach Nappe (Fügenschuh et al. 2000) as, for example, given in the geological map sheet Sterzing (Rockenschaub and Nowotny 2011) is unjustified because everywhere else, the Alpine and Pre-Alpine metamorphism of the Steinach Nappe is too low for garnet growth. The tectonostratigraphic sequence from bottom to top of Ötztal basement, Brenner Mesozoic cover, and the Schneeberg Complex has to be considered as the configuration prior to Eoalpine high-grade metamorphism (i.e. Eoalpine garnet growth), Eoalpine folding, and Tertiary faulting.

The Mesozoic rocks of the Moarer Weißen are overlain by slivers of the Schneeberg Complex (LK18-8) similar to the slivers of the Telfer Weißen area (Figs. 2, 5). From east to west this tectonostratigraphic sequence was folded later with increasing intensity. This caused the overturning of the sequence of Gürtelspitz. At the Gürtelspitz summit, rocks of the Ötztal basement overlie their own Mesozoic cover, visible at the southeastern slope (Fig. 6). The Mesozoic itself is overturned, too, with Permo-Triassic metaclastic rocks over Triassic metacarbonates. The bottom part of the Gürtelwand is built up by rocks of the Schneeberg Complex, the contact between these and the Mesozoic representing an overturned thrust. Directly east of the Moarer Weißen Dietrich (1983) described garnet growth in the Permo-Triassic rocks 
Fig. 5 Schematic, representative cross sections of the southeastern Ötztal Nappe. See Fig. 1b for positions cross section $A-A^{\prime}$

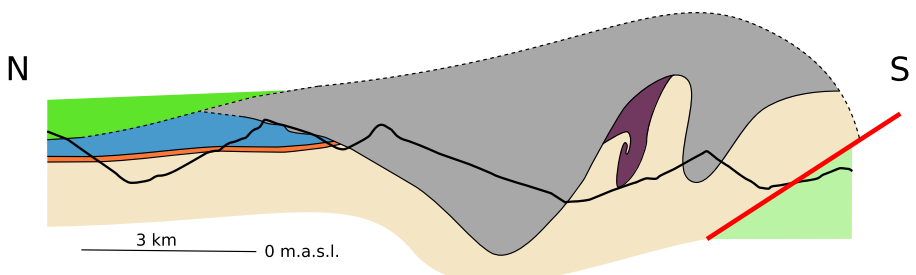

cross section B-B'

$\mathrm{N}$

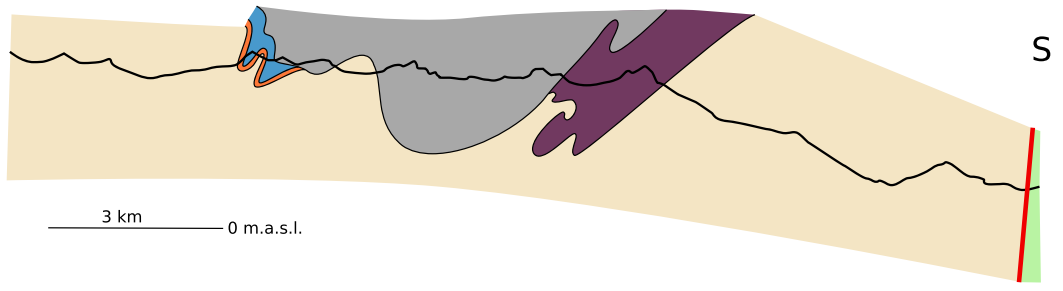

cross section $\mathrm{C}^{-\mathrm{C}^{\prime}}$

NW

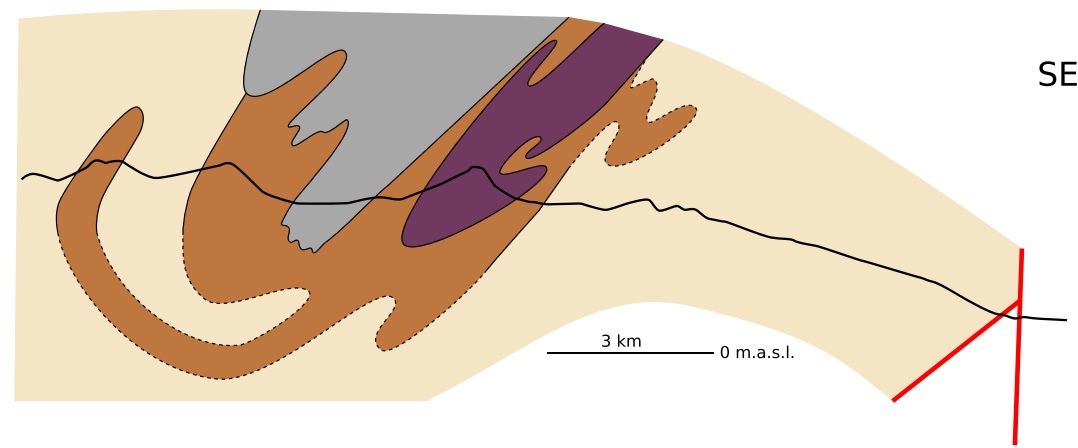

at Egetenjoch. This is consistent with the metamorphic gradient in the Mesozoic rocks, with temperatures increasing from northeast to southwest (Purtscheller et al. 1987a; see our Fig. 2a).

South of the main outcrop of the Schneeberg Complex, the absence of Mesozoic rocks as a structural marker makes the tectonic reconstruction more difficult. The Mesozoic rocks are missing in the South, because the southern contact of the Schneeberg Complex is a deeper part of the Schneeberg Thrust than the part north of the Schneeberg Complex.

\section{The border between the Ötztal Complex s.str. and the Texel Complex}

In the following we will review the development of interpretations of the contact between the Texel Complex and the Ötztal Complex s.str. (Fig. 7). The separation of the Texel Complex to the Southeast from the Ötztal Complex s.str. to the Northwest is obvious along the strike of the Schneeberg Complex. To the East the Brenner Fault terminates all three units. North of Sterzing, the Ötztal Complex s.str. underlies the Schneeberg Complex. South of Sterzing, the Brenner Fault separates rocks of the Schneeberg Complex from Penninic rocks of the Tauern Window. Here, no contact between the Ötztal Complex s.str. and the Texel Complex is

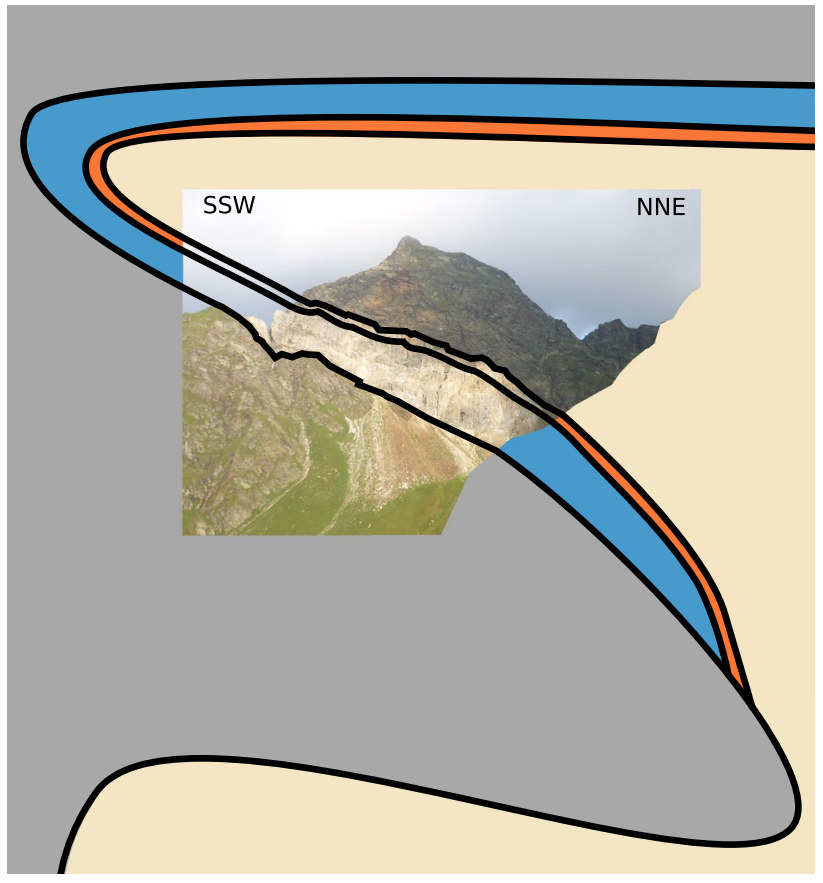

Fig. 6 Photograph of the Gürtelspitz from St. Martin am Schneeberg (Fig. 1c) embedded in the interpretational sketch of an overturned fold. Units coloured as in Fig. 1 
exposed at the surface. To the West the Schneeberg Complex ends in its westernmost syncline (Schrottner Syncline). From here towards southwest, no mappable separation exists between the Ötztal Complex s.str. and the Texel Complex. While the area is fully mapped, a consistent geological map of small scale is not available yet. This is also due to many map sheet edges. An extensive resource for the maps of the geological surveys of the area is the online map application GeoBrowser of the Autonomous Province Bolzano - South Tyrol (2021). The lithological continuity between the Ötztal Complex and the Texel Complex is recorded on all abovementioned map sheets.

In an early attempt to subdivide units into nappes, Staub (1924) described the Texelgruppe as part of the Campo Nappe and therefore was probably one of the first authors describing a boundary between the Ötztal Complex s.str. and the Texel Complex. Sander (1929) disproved this border, as it cut across the Mesozoic cover of the Ötztal Complex s.str., the Schneeberg Complex, and the Laas Series. Further, this border could only be possibly located south of the Laas Series, but this would contradict the nappe definitions of Staub (1924). With this exception no study mentioned a boundary between the Ötztal Complex s.str. and the Texel Complex until Schmid and Haas (1989) did. Before the publication of Schmid and Haas (1989), the Ötztal Complex s.str. and the Texel Complex were treated as a coherent unit (e.g. Schmidegg 1932, 1964; Schmidt 1965; Baggio et al. 1971; Satir 1976; Helbig and Schmidt 1978; Mauracher 1980; Zanettin and Justin-Visentin 1980; Hoinkes 1981, 1983; Frank et al. 1987; Hoinkes et al. 1987; Purtscheller et al. 1987a, b; Thöni and Hoinkes 1987; van Gool et al. 1987).

Schmid and Haas (1989) described a boundary, in this case diffuse and disappearing towards east, between the Texel Complex and the Ötztal Complex s.str. In search for the eastern continuation of the E-W striking Vinschgau Shear Zone, the basal thrust of the Ötztal Nappe, they extrapolated this intrabasement shear zone into a zone of
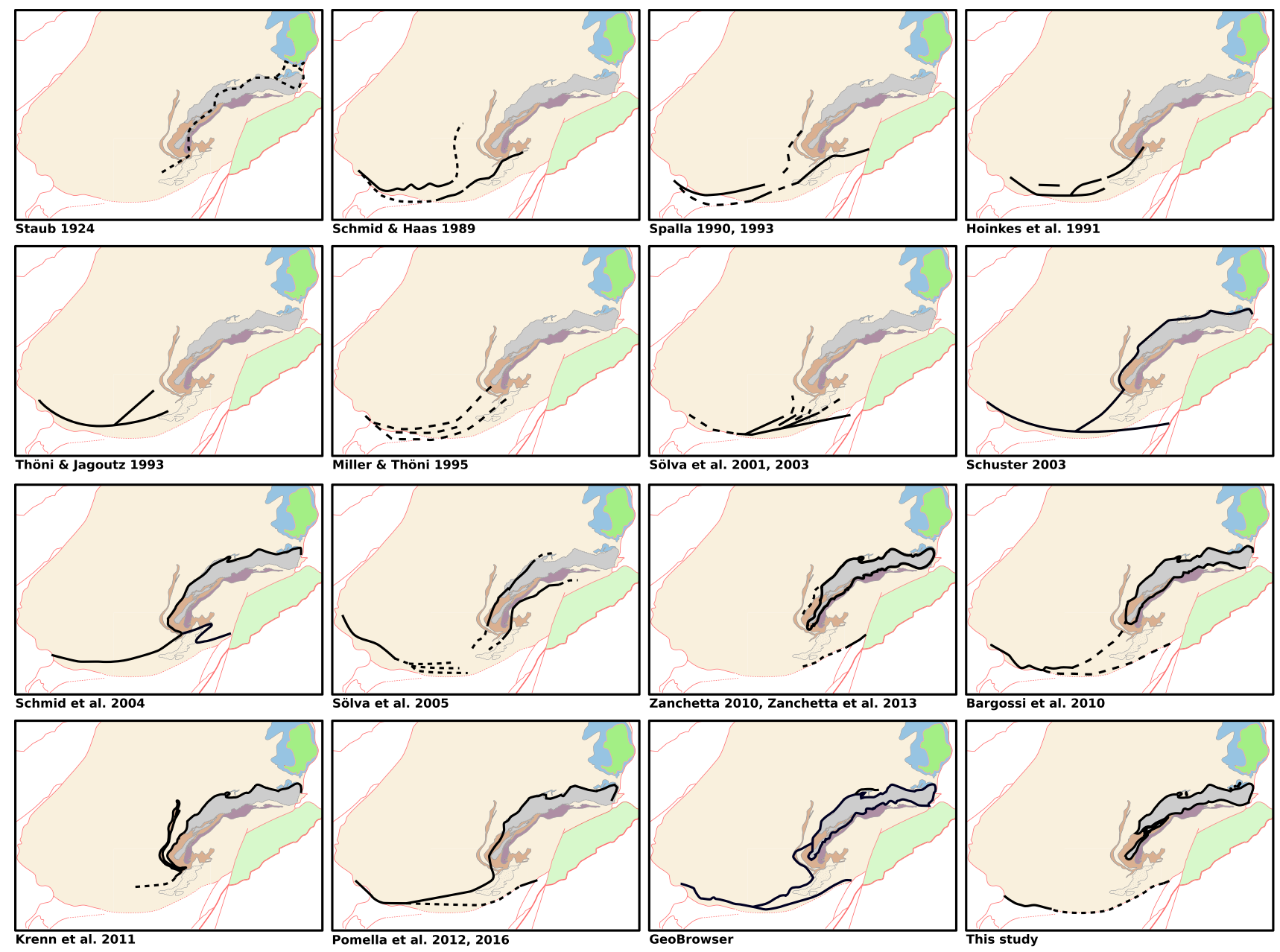

Fig. 7 Tectonic borders between the Ötztal Complex s.str., Campo Complex, Texel Complex, and Schneeberg Complex and related shear zones (Vinschgau Shear Zone and Schneeberg Normal Fault Zone) redrawn from maps in literature 
large-scale folding and concluded that the Vinschgau Shear Zone towards east "is transformed into more diffuse straining associated with folding", i.e. the separation between Ötztal and Campo nappes dies out towards east. The southern border of this zone of large-scale folding is described along strongly sheared rocks north of the Tschigott granodiorite body and south of the Lodner syncline (southernmost Laas Series). A problem with this interpretation is that Schmid and Haas (1989) assumed no Eoalpine deformation in the Texel Complex, referring to Helbig and Schmidt (1978) and van Gool et al. (1987). This southern limit of the Vinschgau Shear Zone is therefore, according to Schmid and Haas (1989), a boundary between units with Eoalpine deformation (Vinschgau Shear Zone) and without such deformation (Texel Complex). However, Eoalpine deformation of the Texel Complex was described by Spalla $(1990,1993)$, Gregnanin et al. (1995), and Sölva et al. (2001). The strongly deformed rocks along the border of the Tschigott granodiorite most likely result from strain localization adjacent to this competent body and not from a major tectonic contact. The northwestern limit of the Vinschgau Shear Zone is not further defined and is shown as a dashed line blindly ending in the Ötztal Complex s.str. by Schmid and Haas (1989), because a discrimination between Variscan and Eoalpine structures is not possible in this area. In addition to these problems, it is hard to imagine that the displacement of the Vinschgau Shear Zone, estimated to be $45 \mathrm{~km}$ by Schmid and Haas (1989), dies out towards east over such a short distance. Therefore, we do not follow the interpretation of Schmid and Haas (1989) but assume that the Vinschgau Shear Zone extends eastwards into the Thurnstein Mylonites. However, a detailed structural study of the area at the eastern end of the VSZ would be necessary to finally decide about this question.

Following Schmid and Haas (1989), an eastern continuation of the Vinschgau Shear Zone towards the Schneeberg Complex is depicted in later publications, sometimes by vague dotted or dashed lines or lines accompanied by question marks, in either a similar configuration (e.g. Spalla 1990,1993 ) or in simplified or modified versions (e.g. Hoinkes et al. 1991; Thöni and Jagoutz 1993; Miller and Thöni 1995; Schuster and Frank 1999; Sölva et al. 2001, 2003; Schuster et al. 2001; Schuster 2003; Schmid et al. 2004) (Fig. 7).

Schuster et al. (2001) correlated units by their Permian metamorphic (HT-LP) imprint related to the Permian rifting. The Texel Complex belongs to the units with a Permian thermal imprint. As the Ötztal Complex s.str. is without a Permian thermal imprint, Schuster et al. (2001) drew a boundary between the two. Near the southwestern end of the Schneeberg Complex, this boundary crosscuts lithological boundaries at almost a right angle. Permian pegmatites are known from the northern Texel Complex (Ratschingser
Tal, Hohe Kreuzspitze) (e.g. Sassi 1968; Schneider 2013), but Bargossi et al. (2010) showed that there are no significant pegmatites in the southern Texel Complex and pegmatites south of the Thurnstein mylonites belong to the Campo Complex. No Permian metamorphic mineral (e.g. garnet) ages are known for the Ötztal Complex s.str., the Texel Complex, or the Schneeberg Complex (e.g. Thöni 2002). The border configuration of Schuster et al. (2001) is therefore not constrained by Permian characteristics but follows vaguely the border configuration of Schmid and Haas (1989). Schuster (2003) adopted this border configuration and included the Texel Complex and the Schneeberg Complex in the high-pressure extrusion wedge of the lower plate of the Eoalpine subduction and the Ötztal Complex s.str. in an upper plate position. This nappe configuration is adopted by Schmid et al. (2004), but with the northern border of the Campo Complex circumnavigating the Tschigott granodiorite to the North. Thus, the Tschigott granodiorite is part of the Campo Complex in Schmid et al. (2004) but part of the Texel Complex in Schuster et al. (2001). At the point where the Tschigott granodiorite (Campo Complex) is closest to the Schneeberg Complex, Schmid et al. (2004) connected the northwestern border of the Schneeberg Complex (high-pressure extrusion wedge) with the northern border of the Campo Complex (southern boundary of the Vinschgau Shear Zone after Schmid and Haas 1989). In this configuration the Ötztal Complex s.str. is not in contact with the Texel Complex. Schmid et al. (2004) included the Schneeberg Frame Zone in the Schneeberg Complex. Our results show that there is no tectonic border between the Schneeberg Frame Zone, the Ötztal Complex s.str., and the Texel Complex. In Schmid et al. (2004), southeast of the Tschigott granodiorite the northern border of the Campo Complex follows the Vinschgau Valley deposits. The border between the Texel Complex and the Campo Complex east of the Tschigott granodiorite is unmappable, because the rocks north and south of this artificial border are the same (e.g. Bargossi et al. 2010).

Sölva et al. (2005) presented structural and geochronological data for the Texel Complex, the Schneeberg Complex, and the adjacent Ötztal Complex s.str. Their geodynamic interpretation includes the Schneeberg Normal Fault Zone, a shear zone at least the size of the Schneeberg Complex. The north-western limit of the Schneeberg Complex is defined as the upper limit of the proposed extrusion wedge, including the Texel Complex. This border roots in the premise of a Variscan Ötztal Complex s.str. versus an Eoalpine Schneeberg Complex and Texel Complex. However, neither structural features nor the geochronological record can support the co-occurrence of the lithological border of the Schneeberg Complex with the upper limit of an extrusion wedge. Eoalpine structural features (van Gool et al. 1987) and mineral ages (Thöni and Hoinkes 1987) are reported 
far into the Ötztal Complex s.str. The W-WNW-directed sense of shear is reported throughout all units. The contrast of pre-Eoalpine versus only Eoalpine features is located at the Schneeberg Thrust, and not at the upper boundary of the putative Schneeberg Normal Fault Zone.

The introduction of the Schneeberg Normal Fault Zone (Sölva et al. 2005) encouraged authors to link the northern boundary of the Schneeberg Complex at various locations with the Vinschgau Shear Zone for various geodynamic interpretations (e.g. Bargossi et al. 2010; Zanchetta 2010; Krenn et al. 2011; Pomella et al. 2012, 2016). This link functions as the border between the Ötztal Complex s.str. and the Texel Complex, but it is not mappable in the field because the rocks on both sides are the same and it locally cuts across lithological boundaries at a high angle, in places where no offset can be found in the field. Krenn et al. (2011) and Zanchetta (2010) suggested such a connection but showed only the eastern part on their respective maps. This is the reason why also our maps in Fig. 7 show only the eastern parts of the boundaries proposed by these authors.

In some publications (e.g. Bargossi et al. 2010; Zanchetta 2010; Zanchetta et al. 2013; Pomella et al. 2012, 2016) the border between the Ötztal Complex s.str. and the Texel Complex is the northern branch of the eastern prolongation of the Vinschgau Shear Zone, while the southern branch extends under the Vinschgau valley deposits to the Thurnstein Mylonites and puts the Texel Complex in a wedge position. Note that in the East the Marlengo Slice after Bargossi et al. (2010) or the Forst Line (Spiess et al. 2001) as part of the Giudicarie Fault System truncates the Thurnstein Mylonites. Confusion about the correlation of the Thurnstein Mylonites with the Forst Line and vice versa is abundant in the literature (e.g. Spiess 1995; Viola et al. 2001; Pomella et al. 2016). The two sample localities for apatite and zircon fission track data of Viola et al. (2001) are not, as assumed by the authors, north and south of the Thurnstein mylonites, but are west of the Forst Line (north of the Thurnstein Mylonites) and east of the Forst Line (in the Marlengo Slice), so differences in apatite and zircon fission track age data are related to the Forst Line, not the Thurnstein mylonites. Although faults were marked in the area from Thurnstein to Saltaus on the geological map sheet Meran (scale 1: 100,000) (Baggio et al. 1971), the situation is much clearer on the new geological map sheet Meran (scale 1: 50.000) (Bargossi et al. 2010). A continuation of the Thurnstein Mylonites into the Jaufen Fault to the Northeast was proposed by Viola et al. (2001), but Rosenberg et al. (2007) and Bargossi et al. (2010) doubted this interpretation due to different characteristics of the footwalls and different orientations of stretching lineations. We follow Bargossi et al. (2010) and assume the Thurnstein Mylonites are related to the Vinschgau Shear Zone and not to the Jaufen fault. The younger faults of Giudicarie, Passeier, and Jaufen (see Müller et al. 2001, for age constraints) are not relevant for the relationships between Campo Complex, Ötztal Complex s.str., and Texel Complex discussed here.

Recent interpretations of the Eoalpine geodynamics of the Texel Complex include the models of Krenn et al. (2011) and Pomella et al. (2016). In the model of Krenn et al. (2011), a first phase of thrusting brings the Ötztal Complex s.str. onto the Texel Complex, with the Schneeberg Complex in between. These early thrust contacts are strongly folded in a second phase of (out-of-sequence) thrusting along the Vinschgau Shear Zone. According to Pomella et al. (2016), the northwest-dipping attitude of the foliation in the western part of the Schneeberg Complex does not reflect topNW normal shearing (Schneeberg Normal Fault Zone), as assumed by Sölva et al. (2005), but results from northwestward rotation of units that originally dipped southeast. This agrees with our own interpretation. The boundaries between Texel and Ötztal complexes drawn by Krenn et al. (2011) and Pomella et al. (2016) suffer from the same shortcomings as the boundaries assumed by earlier authors: they locally cut across undisturbed layering and are not supported by lithological contrasts.

To conclude, all attempts to introduce a tectonic separation between the Ötztal s.str. and Texel complexes resulted in boundaries which either cross undisturbed lithological layering at high angles (e.g. Schuster and Frank 1999; Schuster et al. 2001; Pomella et al. 2012, 2016; GeoBrowser) or which are completely unsupported by field relations, e.g. the artificial tectonic boundary between the Tschigott granodiorite (Campo Nappe according to Schmid et al. 2004) and its country rocks on the east side (Texel Complex according to Schmid et al. 2004). Consequently, there is no way to identify Ötztal s.str. and Texel complex as different tectonic units. The assumption of a major northwest-dipping normal fault zone, the Schneeberg Normal Fault Zone of Sölva et al. (2005), is problematic as well, because as shown above there is no sudden change in Eoalpine deformation or metamorphism across the Schneeberg Complex. The Ötztal Nappe is a continuous unit with southeastward increasing Alpine metamorphism.

\section{Tectonic model}

In summary, a tectonic border between the Ötztal Complex s.str. and the Texel Complex cannot be defined. Here we present a conceptual tectonic model (Fig. 8) which is in line with the available information and emphasizes the existence of a unified Ötztal Nappe with an Eoalpine high-pressure part.

First we have to explain the fact that units in the footwall of the Schneeberg Thrust show medium- to highgrade Variscan metamorphism, whereas the Schneeberg Complex in the hanging wall of this thrust is free 
of Variscan garnet, i.e. it was affected by only low-grade Variscan metamorphism or none at all. This cannot result from Eoalpine thrusting alone because thrusting brings deeper-level rocks onto higher-level ones, i.e. the opposite of what is observed here. A pre-Alpine tectonic contact is necessary to explain this situation. Therefore, as the first phase in our model (Fig. 8a), we assume a Late- to Post-Variscan normal fault in the position of the later Schneeberg Thrust, between the Schneeberg Complex and the underlying units. The exhumation of rocks with Variscan high-grade metamorphism (Ötztal Complex, Schneeberg Frame Zone, Laas Series and Texel Complex: with Variscan garnet) relative to rocks with Variscan low-grade metamorphism at most (Schneeberg Complex: without Variscan garnet) is most easily explained by such a normal fault. In order to fit the structural situation, we assume that the normal fault dipped south or southeast. In the Southern Alps, about $145 \mathrm{~km}$ southwest of our study area, a major southeast-dipping low-angle normal fault of Early Permian age has indeed been identified (Grassi Detachment Fault; Froitzheim et al. 2008; Pohl et al. 2018). This fault was spared from Alpine reactivation because Alpine thrusting in the Southern Alps was directed towards south, for which the orientation of the Grassi Detachment Fault was unsuitable. A very similar low-angle normal fault may have existed in the Austroalpine Ötztal nappe, at the base of the Schneeberg Complex, where it was prone for Eoalpine reactivation as a thrust. We can assume a Permian upper crustal position of the Ötztal nappe and the Schneeberg Complex, because no Permian metamorphism is observed. In the Texel Complex Permian pegmatites indicate a depth of ca. 10-15 km (Sassi 1968, Schneider 2013, Schuster et al. 2017). North of the Schneeberg Complex, the existence of Permo-Mesozoic sediments shows a near-surface position during the Permian. This trend supports the dip direction of the Permian normal fault from shallow north of the Schneeberg Complex to deeper south of it.

In a next step (Fig. 8b), Permo-Mesozoic sediments (Brenner Mesozoics) were deposited with an erosional unconformity on the basement units, including the Schneeberg Complex. This sediment cover also sealed the hypothesized Early Permian normal fault. The same is observed in the case of the Grassi Detachment Fault in the Southern Alps, where the topography resulting from Early Permian normal faulting was eroded and unconformably sealed by Late Permian and younger sediments. A Permo-Mesozoic

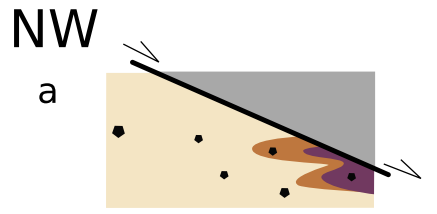

b

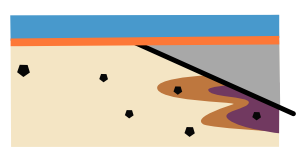

d
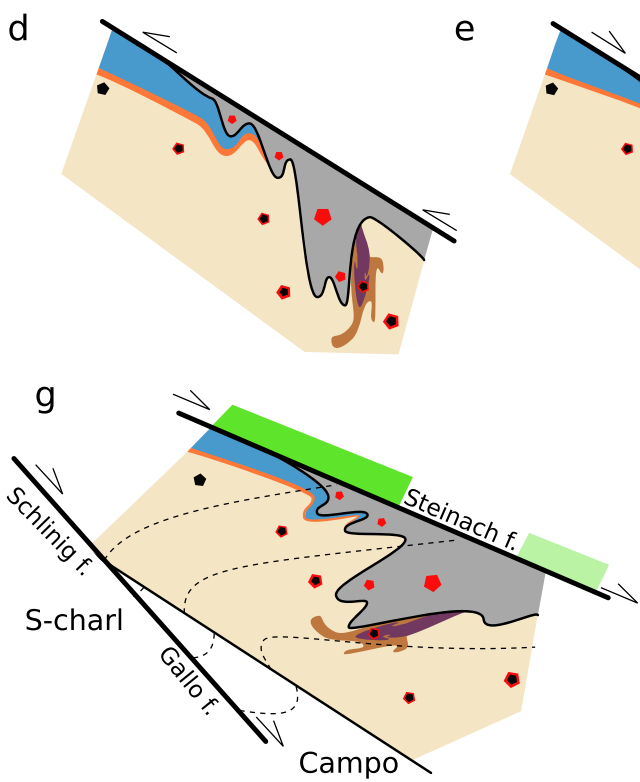

Fig. 8 Tectonic model for the Ötztal Nappe. a Late- to Post-Variscan normal faulting; b Permo-Mesozoic sedimentation; c Activity of the Schneeberg Thrust predating Eoalpine peak metamorphism; d Eoal-
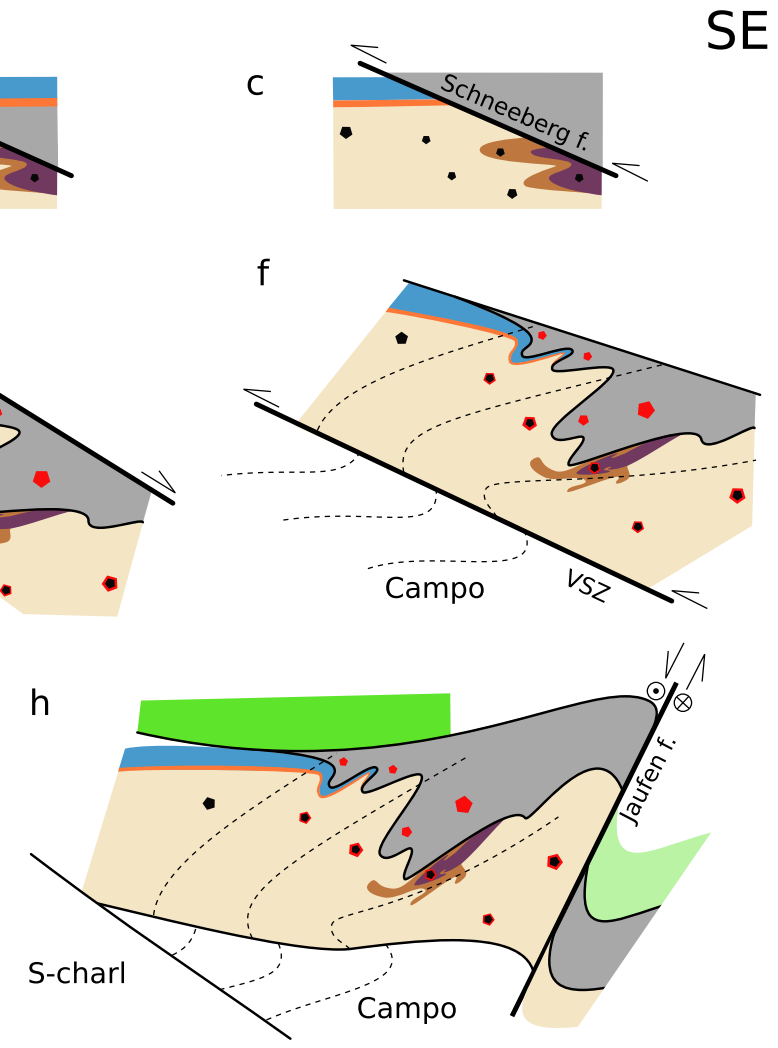

pine subduction and folding of the Schneeberg Thrust; e Initial exhumation; f Vinschgau Shear Zone thrusting; g Late Cretaceous extensional tectonics; $\mathbf{h}$ Tertiary indentation tectonics. See text for details 
cover of the Schneeberg Complex must have existed but has been lost due to erosion.

In the next step (Fig. 8c), the low-angle normal fault was reactivated as the north- or northwest-directed Schneeberg Thrust, displacing the Schneeberg Complex over the units with Variscan garnet and thrusting it up onto the Brenner Mesozoics. We assume that this occurred before Eoalpine garnet growth because Eoalpine garnet grew equally on both sides of the Schneeberg Thrust. After this phase of thrusting all these units became the Ötztal Nappe and were thereafter deformed and metamorphosed as a coherent unit. The Schneeberg Thrust reactivated the earlier (Pre-Mesozoic) normal fault, which explains that it has the characteristics of a thrust (Pre-Mesozoic Schneeberg Complex on top of Brenner Mesozoic) but shows a normal fault character with respect to Variscan metamorphism (high grade in the footwall, low grade in the hanging wall).

The Ötztal Nappe was subducted towards southeast as part of the Lower Central Austroalpine, leading to the southeastward-increasing Eoalpine metamorphism which reached eclogite facies in the Texel Complex. The peak pressure for eclogites of the Texel Complex was about 1.4 GPa according to Habler et al. (2006) or $2.8 \mathrm{GPa}$ according to Zanchetta et al. (2013). Hence, the maximum depth of subduction is ill constrained, $100 \mathrm{~km}$ according to Zanchetta et al. (2013) or about half of this amount according to Habler et al. (2006), always assuming near-lithostatic pressure. The former pressure determination is hard to reconcile with our model, as it would require a high amount of shortening of the Ötztal Nappe during or after exhumation. Therefore, we would prefer the moderate pressure determined by Habler et al. (2006) for the Eoalpine peak. The near-ultrahigh-pressure metamorphism of Zanchetta et al. (2013) might be a Variscan feature. Today, the Ötztal Nappe is overlain by the Steinach Nappe to the East and is in contact to the Meran-Mauls Basement (Upper Central Austroalpine) to the Southeast. These two units can, however, not represent the roof under which the Ötztal Nappe was subducted because they have always resided at much shallower levels of the crust, as shown by their low-grade (Eo)Alpine metamorphism. Rather, the roof of the subduction zone was formed by a lower crustal and mantle wedge underlying these units. The roof of the subduction zone is at present nowhere exposed at the surface. For the easternmost part of the Eoalpine HP/UHP belt (Koralpe-Pohorje), Janák et al. $(2004,2015)$ proposed that it was removed by downward extraction. The same may apply for our study area.

Eoalpine garnet grew during or at the end of the subduction. The southeastern Ötztal Nappe was deformed internally into large, upright folds which also folded the Schneeberg Thrust (Fig. 8d).

For the initial exhumation of the Ötztal Nappe we assume top-to-ESE kinematics along the upper boundary of the subduction channel (Fig. 8e). Top-to-ESE kinematics related to the Eoalpine peak metamorphism were reported in the Texel Complex by Sölva et al. (2005). This kinematic framework could be explained by the extraction of the mantle wedge. The earlier folds (formed in Fig. 8d) were rotated into a southeast-facing attitude (Fig. 8e). This relationship is still preserved. The rotation locally led to the overturning of the northwestern fold limbs of synclines, spectacularly exposed at the Gürtelspitz (Fig. 6). W-NW-directed thrusting along the Vinschgau Shear Zone juxtaposed highergrade rocks of the Ötztal Nappe over lower-grade rocks of the Campo Complex (Fig. 8f). This must also have taken place after the peak of Eoalpine metamorphism because the VSZ offsets metamorphic isograds (Schmid and Haas 1989). For the sake of clarity we have shown the initial exhumation (Fig. 8e) and the VSZ thrusting (Fig. 8f) in two separate steps but these processes probably overlapped in time.

The Schlinig-Gallo Fault formed during the Late Cretaceous as a SE-dipping extensional normal fault system below the Ötztal Nappe (Fig. 8g). It exhumed the S-charl Unit relative to the Ötztal Nappe and the Campo Complex (Froitzheim et al. 1997). The structurally higher, equally southeast-dipping Steinach Normal Fault emplaced the Steinach Nappe and the Meran-Mauls Basement on the Ötztal Nappe (Fügenschuh et al. 2000). Thereby, the Ötztal Nappe was exhumed relative to the Meran-Mauls Basement (Viola et al. 2001) and relative to the Steinach Nappe (Fügenschuh et al. 2000).

Tertiary tectonics (Fig. 8h) involved renewed large-scale folding and rotation of structures into a northwest-dipping attitude (Pomella et al. 2016). This led to the formation of the northwest-dipping Jaufen Fault which had originally been a deep part of the southeast-dipping Steinach Normal Fault. The deepest part of the Steinach Fault may exist southeast of the Jaufen Fault between Meran-Mauls Basement and the underlying Schneeberg Complex. After that rotation, the Jaufen Fault was overprinted by sinistral and northwest-side-down normal fault movement, i.e. opposite to the Late Cretaceous relative motion (Fig. 8h; Viola et al. 2001). This was related to northward indentation of Adria along the Giudicarie Fault System (Viola et al. 2001; Pomella et al. 2012; Klotz et al. 2019).

\section{Conclusions}

1. Garnets in the Schneeberg Complex are single phased (Eoalpine), whereas all other units-Ötztal Complex s.str., Texel Complex, Schneeberg Frame Zone, Lass Series-have two-phased (Variscan and Eoalpine) garnet. The Schneeberg Complex represents a high level of the Variscan orogenic crust (low-grade or unmetamorphic Paleozoic sedimentary rocks), the other units a 
deeper structural level affected by Variscan medium- to high-grade metamorphism. These two levels were most likely juxtaposed by a Late- to Post-Varsican, S- or SEdipping low-angle normal fault in the position of the later (Early Eoalpine) Schneeberg Thrust.

2. The Schneeberg Thrust reactivated this low-angle normal fault during the Cretaceous at an early stage of the Eoalpine Orogeny and emplaced the Schneeberg Complex over the Brenner Mesozoic cover of the Ötztal Complex s.str. The thrust was deformed by upright folds in a later stage of the Eoalpine subduction. Subductionrelated metamorphism and deformation affected the Schneeberg Complex and the other units together, as parts of one coherent Ötztal Nappe.

3. A tectonic boundary between the eclogite-bearing Texel Complex and the Ötztal Complex s.str. cannot be identified in the field. Boundaries proposed by previous authors do not stand ground truthing by structural field observations southwest of the Schneeberg Complex.

4. At present, the base of the Ötztal Nappe is formed by the Vinschgau Shear Zone continuing eastward into the Thurnstein Mylonites, a Late Cretaceous westward thrust postdating Eoalpine peak metamorphism. The top of the Ötztal Nappe is a Late Cretaceous low-angle normal fault, the Steinach Normal Fault, which emplaced units of low Eoalpine metamorphic grade (Steinach Nappe and Meran-Mauls Basement) on the medium- to high-grade metamorphic Ötztal Nappe. This process resembled the Late- to Post-Variscan normal faulting which took place $\sim 200$ Ma earlier.

5. Tertiary indentation led to southeastward rotation and overturning of a deeper part of the Steinach Fault which thereby became the steeply northwest-dipping Jaufen Fault and was reactivated by northwest-side-down normal faulting.

Acknowledgements Helpful comments by Jan Pleuger and an anonymous reviewer helped the authors to improve the article. The authors thank Wolf-Christian Dullo for editorial handling.

Funding Open Access funding enabled and organized by Projekt DEAL. This work was supported by Deutsche Forschungsgemeinschaft (Grant no. 365184787).

Open Access This article is licensed under a Creative Commons Attribution 4.0 International License, which permits use, sharing, adaptation, distribution and reproduction in any medium or format, as long as you give appropriate credit to the original author(s) and the source, provide a link to the Creative Commons licence, and indicate if changes were made. The images or other third party material in this article are included in the article's Creative Commons licence, unless indicated otherwise in a credit line to the material. If material is not included in the article's Creative Commons licence and your intended use is not permitted by statutory regulation or exceeds the permitted use, you will need to obtain permission directly from the copyright holder. To view a copy of this licence, visit http://creativecommons.org/licenses/by/4.0/.

\section{References}

Autonomous Province Bolzano - South Tyrol (2021) GeoBrowser. https://maps.civis.bz.it. Accessed 25 May 2021

Baggio P, Friz C, Gatto GO, Gatto P, Gregnanini A, Justin-Visentin E, Lorenzoni S, Mezzacasa G, Morgante S, Omenetto EM, Sassi FP, Zanettin-Lorenzoni EBZ, Zulian T (1971) Note illustrative della Carta Geologica D'Italia 1:100.000. In: Foglio 4/Merano Carta Geologica D'Italia 1:100.000, Nuova Tecnica Grafica, Roma

Bargossi GM, Bove G, Cucato M, Gregnanin A, Morelli C, Moretti A, Poli S, Zanchetta S, Zanchi A (2010) Erläuterungen zur geologischen Karte von Italien im Maßstab 1:50.000 Blatt 013 Meran. In: CARG. ISPRA, Istituto Superiore per la Protezione e la Ricerca Ambientale, Roma

Behrmann JH (1988) Crustal-scale extension in a convergent orogen: the Sterzing-Steinach mylonite zone in the Eastern Alps. Geodin Acta 2:63-73. https://doi.org/10.1080/09853111.1988. 11105157

Bousquet R, Oberhänsli R, Schmid SM, Berger A, Wiederkehr M, Robert C, Möller A, Rosenberg C, Zeilinger G, Molli G, Koller F (2012) Metamorphic framework of the Alps. In: CCGM/CGMW (Commission for the Geological Map of the World, Paris)

De Pieri R, Galetti G (1972) Analisi alla microsonda di granati zonati di scisti austro-alpini dell'Alta Val Passiria (Alto Adige). Mem Ist Geol Miner Univ Padova 29:1-33

Dietrich H (1983) Zur Petrologie und Metamorphose des Brennermesozoikums (Stubaier Alpen, Tirol). Tschermaks Miner Petrol Mitt $31: 235-257$

Elias J (1998) The thermal history of the Otztal-Stubai complex (Tyrol, Austria/Italy) in the Light of the Lateral Extrusion Model. In: Dissertation, University of Tübingen

Frank W, Hoinkes G, Purtscheller F, Thöni M (1987) The Austroalpine unit west of the Hohe Tauern: the Ötztal-Stubai complex as an example for the Eoalpine metamorphic evolution. In: Flügel HW, Faupl P (eds) Geodynamics of the Eastern Alps. Deuticke, Vienna, pp 179-225

Frizzo P (2002) Geologisch Lagerstättenkundliche Karte des Verzungsdistrikts St. Martin am Schneeberg—Pflersch, Maßstab 1:25.000. In: Disegno G Mezzacasa Padova, Grafica V Mair Tesimo

Froitzheim N, Conti E, van Daalen M (1997) Late Cretaceous, synorogenic, low-angle normal faulting along the Schlinig fault (Switzerland, Italy, Austria) and its significance for the tectonics of the Eastern Alps. Tectonophysics 280:267-293

Froitzheim N, Derks JF, Walter JM, Sciunnach D (2008) Evolution of an Early Permian extensional detachment fault from synintrusive, mylonitic flow to brittle faulting (Grassi Detachment Fault, Orobic Anticline, Southern Alps, Italy). In: Siegesmund S, Fügenschuh B, Froitzheim N (eds) Tectonic aspects of the Alpine-DinarideCarpathian system. Geological Society, London, Special Publications, vol 298, pp 69-82

Fügenschuh B, Mancktelow NS, Seward D (2000) Cretaceous to Neogene cooling and exhumation history of the Oetztal-Stubai basement complex, eastern Alps: a structural and fission track study. Tectonics 19:905-918. https://doi.org/10.1029/2000TC900014

Gregnanin A, Valle M (1995) Deformation and metamorphism in the Austroalpine Ötztal-Stubai complex (part II): early-Alpine evolution in basement and cover. Boll Soc Geol It 114:393-409

Gregnanin A, Barattieri M, Corona P, Valle M (1995) Deformation and metamorphism in the Austroalpine Ötztal-Stubai complex (part I): the basement. Boll Soc Geol It 114:373-392 
Habler G, Thöni M, Sölva H (2006) Tracing the high pressure stage in the polymetamorphic Texel Complex (Austroalpine basement unit, Eastern Alps): P-T-t-d constraints. Miner Petrol 88:269-296. https://doi.org/10.1007/s00710-006-0143-7

Hammer W (1926) Note illustrative della Carta Geologica delle Tre Venezie. In: Foglio Passo di Resia, Società Cooperativa Tipigrafica, Padova

Hauke M, Froitzheim N, Nagel TJ, Miladinova I, Fassmer K, Fonseca ROC, Sprung P, Münker C (2019) Two high-pressure metamorphic events, Variscan and Alpine, dated by Lu-Hf in an eclogite complex of the Austroalpine nappes (Schobergruppe, Austria). Int J Earth Sci 108:1317-1331. https://doi.org/10.1007/ s00531-019-01708-8

Hawkins AT, Selverstone J, Brearley AJ, Beane RJ, Ketcham RA, Carlson WD (2007) Origin and mechanical significance of honeycomb garnet in high-pressure metasedimentary rocks from the Tauern Window, Eastern Alps. J Metamorph Geol 25:565-583. https://doi.org/10.1111/j.1525-1314.2007.00714.x

Helbig P, Schmidt K (1978) Zur Tektonik und Petrogenese am W-Ende des Schneeberger Zuges (Ostalpen). Jahrb Geol Bundesanst 121:177-217

Hofmann T, Cernajsek T (1993) Zur historischen Entwicklung geologischer Kartierung in Tirol. Veröff Tirol Landesmus Ferdinandeum 73:13-32

Hoinkes G (1978) Zur Mineralchemie und Metamorphose toniger und mergeliger Zwischenlagen in Marmoren des südwestlichen Schneebergerzuges (Ötztaler Alpen, Südtirol). N Jb Miner Abh 131:272-303

Hoinkes G (1981) Mineralreaktionen und Metamorphosebedingungen in Metapeliten des westlichen Schneebergerzuges und des angrenzenden Altkristallins (Ötztaler Alpen). Tschermaks Miner Petrol Mitt 28:31-54

Hoinkes G (1983) Cretaceous metamorphism of metacarbonates in the Austroalpine Schneeberg complex, Tyrol. Schweiz Miner Petro Mitt 63:95-114

Hoinkes G, Frank W, Mauracher J, Peschel R, Purtscheller F, Tessadri R (1987) Petrography of the Schneeberg complex. In: Flügel HW, Faupl P (eds) Geodynamics of the Eastern Alps. Deuticke, Vienna, pp 190-199

Hoinkes G, Kostner A, Thöni M (1991) Petrologic constraints for Eoalpine eclogite facies metamorphism in the Austroalpine Ötztal basement. Miner Petrol 43:237-254. https://doi.org/10. 1007/BF01164529

Holzmann J, Tropper P (2013) Petrologie der Rahmengesteine der $\mathrm{Pb}-\mathrm{Zn}$ Lagerstätte Schneebrg im Lazzachertal (S-Tirol, Italien). Geol Alp 10:27-46

ISPRA (Istituto Superiore per la Protezione e la Ricerca Ambientale, Dipartimento per il servicio geologico d'Italia (1925) Carta Geologica delle Tre Venezie. In: Foglio 2-3 Passo di Resiá. Carta Geologica d'Italia Scala 1:100.000. ISPRA, Roma

ISPRA (Istituto Superiore per la Protezione e la Ricerca Ambientale, Dipartimento per il servicio geologico d'Italia (1951) Carta Geologica delle Tre Venezie. In: Foglio 9 Monte Cevedale. Carta Geologica d'Italia Scala 1:100.000. ISPRA, Roma

ISPRA (Istituto Superiore per la Protezione e la Ricerca Ambientale, Dipartimento per il servicio geologico d'Italia (1957) Carta Geologica delle Tre Venezie. In: Foglio 10 Bolzano. Carta Geologica d'Italia Scala 1:100.000. ISPRA, Roma

ISPRA (Istituto Superiore per la Protezione e la Ricerca Ambientale, Dipartimento per il servicio geologico d'Italia (1970) Carta Geologica d'Italia Scala. Foglio 4 Meran. In: Carta Geologica d'Italia Scala 1:100.000. ISPRA, Roma

Janak M, Froitzheim N, Lupták B, Vrabec M, Krogh Ravna EJ (2004) First evidence for ultrahigh-pressure metamorphism of eclogites in Pohorje, Slovenia: tracing deep continental subduction in the Eastern Alps. Tectonics 23:TC5014. https://doi.org/10. 1029/2004TC001641

Janák M, Froitzheim N, Yoshida K, Sasinková V, Nosko M, Kobayashi T, Hirajima T, Vrabec M (2015) Diamond in metasedimentary crustal rocks from Pohorje, Eastern Alps: a window to deep continental subduction. J Metamorph Geol 33:495-512. https://doi.org/10.1111/jmg.12130

Klotz T, Pomella H, Reiser M, Fügenschuh B, Zattin M (2019) Differential uplift on the boundary between the Eastern and the Southern European Alps: thermochronologic constraints from the Brenner Base Tunnel. Terra Nova 31:281-294. https://doi. org/10.1111/ter.12398

Konzett J, Hoinkes G (1996) Paragonite-hornblende assemblages and their petrological significance; an example from the Austroalpine Schneeberg Complex, southern Tyrol. Ital J Metamorph Geol 14:85-101. https://doi.org/10.1111/j.1525-1314.1996. 00085.x

Krenn K, Kurz W, Fritz H, Hoinkes G (2011) Eoalpine tectonics of the Eastern Alps: implications from the evolution of monometamorphic Austroalpine units (Schneeberg and Radenthein Complex). Swiss J Geosci 104:471-491. https://doi.org/10.1007/ s00015-011-0087-8

Kübler H, Müller WE (1962) Die Geologie des Brenner-Mesozoikums zwischen Stubai und Pflerschltal (Tirol). Jahrb Geol Bundesanst 105:173-242

Mair V, Vavtar F, Schölzhorn H, Schölzhorn D (2007) Der Blei-ZinkErzbergbau am Schneeberg, Südtirol. Mitt Österr Miner Ges 153:145-180

Manzotti P, Ballèvre M (2013) Multistage garnet in high-pressure metasediments: Alpine overgrowths on Vairscan detrital grains. Geology 41:1151-1154

Mauracher J (1980) Alpidische und voralpidische Metamorphose und Strukturprägung am Westende des Schneeberger Zuges (Ötztaler Alpen). In: Dissertation, University of Vienna

Miladinova I (2019) The subduction of continental crust-insights from eclogite geochronology and petrology. In: Dissertation, University of Bonn

Miller C, Thöni M (1995) Origin of eclogites from the Austroalpine Ötztal basement (Tirol, Austria): geochemistry and Sm-Nd vs. Rb-Sr systematics. Chem Geol 122:199-225. https://doi.org/10. 1016/0009-2541(95)00033-I

Müller W, Prosser G, Mancktelow NS, Villa IM, Kelley SP, Viola G, Oberli F (2001) Geochronological constraints on the evolution of the periadriatic fault system (Alps). Int J Earth Sci 90:623-653. https://doi.org/10.1007/s005310000187

Pedevilla A, Tropper P (2012) Petrographie des Übergangs vom Schneeberg Complex in den Ötztal Complex entlang der Timmelsjoch Paßstrasse (Südtirol, Italien). Mitt Österr Miner Ges 158:27-42

Pohl F, Froitzheim N, Obermüller G, Tomaschek F, Schröder O, Nagel TJ, Sciunnach D, Heuser A (2018) Kinematics and age of synintrusive detachment faulting in the Southern Alps: evidence for Early Permian crustal extension and implications for the Pangea A versus B controversy. Tectonics 37:1-22. https://doi.org/10.1029/ 2018TC004974

Poli S (1991) Reaction spaces and P-T paths: from amphibole ecolgite to greenschist facies in the Austroalpine domain (Oetztal Complex). Contrib Miner Petrol 106:399-416. https://doi.org/10.1007/ BF00321984

Pomella H, Stipp M, Fügenschuh B (2012) Thermochronological record of thrusting and strike-slip faulting along the Giudicarie Fault System (Alps, Northern Italy). Tectonophysics 579:118130. https://doi.org/10.1016/j.tecto.2012.04.015

Pomella H, Flöss D, Speckbacher R, Tropper P, Fügenschuh B (2016) The western end of the Eoalpine High-Pressure Belt (Texel unit, South Tyrol/Italy). Terra Nova 28:60-69. https://doi.org/10.1111/ ter. 12191 
Purtscheller F, Dietrich H, Rammlmair D, Tessadri R (1987a) Rocks affected by Alpine metamorphism only. In: Flügel HW, Faupl P (eds) Geodynamics of the Eastern Alps. Deuticke, Vienna, pp 183-185

Purtscheller F, Haas R, Hoinkes G, Mogessie A, Tessadri R, Veltman C (1987b) Eoalpine metamorphism in the crystalline basement. In: Flügel HW, Faupl P (eds) Geodynamics of the Eastern Alps. Deuticke, Vienna, pp 185-190

Rockenschaub M, Nowotny A (2011) Geological map sheet 175 Sterzing 1:50.000. In: Geol Bundesanst, Vienna

Rode S, Rösel D, Schulz B (2012) Constraints on the Variscan P-T evolution by EMP Th-U-Pb monazite dating in the polymetamorphic Austroalpine Oetztal-Stubai basement (Eastern Alps). Z Dtsch Ges Geowiss 163:43-67

Rosenberg C, Brun JP, Cagnard F, Gapais D (2007) Oblique indentation in the Eastern Alps: insights from laboratory experiments. Tectonics 26:1-23. https://doi.org/10.1029/2006TC001960

Sander B (1920) Tektonik des Schneeberger Gesteinszuges zwischen Sterzing und Meran. Jahrb Geol Staatsanst 70:225-234

Sander B (1929) Erläuterungen zur geologischen Karte Meran-Brixen. Schlernschr 16:1-111

Sassi FP (1968) Petrogenesi dei corpi pegmatoidi di Val Racines (Alto Adige). Mem Museo Trident Sci Nat 17:1-60

Satir M (1976) Rb-Sr- und K-Ar-Altersbestimmungen an Gesteinen und Mineralien des südlichen Ötztalkristallins und der westlichen Hohen Tauern. Geol Rundsch 65:394-410

Schmid SM, Haas R (1989) Transition from near-surface thrusting to intrabasement decollement, Schlinig Thrust, Eastern Alps. Tectonics 8:697-718. https://doi.org/10.1029/TC008i004p00697

Schmid SM, Fügenschuh B, Kissling E, Schuster R (2004) Tectonic map and overall architecture of the Alpine orogen. Eclogae Geol Helv 97:93-117. https://doi.org/10.1007/s00015-004-1113-x

Schmidegg O (1964) Die Ötztaler Schubmasse und ihre Umgebung. Verh Geol Bundesanst 1:24-47

Schmidegg O (1932) Geologische Spezialkarte der Republik Österreich, Blatt Sölden und St. Leonhard. Maßstab 1:75.000. In: Geol Reichsanst, Vienna

Schmidt K (1965) Zum Bau der südlichen Ötztaler und Stubaier Alpen. In: Verh Geol Bundesanst G, pp 199-213

Schneider T (2013) Petrologie und Strukturgeologie eines Nb-Ta-SnU-P-Be-führenden Pegmatits im Austroalpinen Texel-Komplex. Universtiy of Innsbruck, Masterthesis

Schulz B, Krause J, Zimmermann R (2019) Electron microprobe petrochronology of monazite-bearing garnet micaschists in the Oetztal-Stubai Complex (Alpeiner Valley, Stubai). Swiss J Geosci 112:597-617

Schuster R (2003) Das eo-Alpidische Ereignis in den Ostalpen: Plattentektonische Situation und interne Struktur des Ostalpinen Kristallins. In: Rockenschaub M (ed) Arbeitstagung 2003 der Geologischen Bundesanstalt Trins im Gschnitztal. Geol Bundesanst, Vienna, pp 141-159

Schuster R, Frank W (1999) Metamorphic evolution of the Austroalpine units east of the Tauern Window: indications for Jurassic strike slip tectonics. Mitt Ges Geol Bergbaustud Österr 42:37-58

Schuster R, Scharbert S, Abart R, Frank W (2001) Permo-Triassic extension and related HT/LP metamorphism in the AustroalpineSouthalpine realm. Mitt Ges Geol Bergbaustud Österr 45:111-141

Schuster R, Ilickovic T, Mali H, Huet B, Schedl A (2017) Permian pegmatites and spodumene pegmatites in the Alps: formation during regional scale high temperature/low pressure metamorphism. NGF Abstr Proc 2:122-125

Selverstone J (1988) Evidence for east-west crustal extension in the eastern Alps: implications for the unroofing history of the Tauern window. Tectonics 7:87-105. https://doi.org/10.1029/tc007i001p00087

Sölva H, Thöni M, Grasemann B, Linner M (2001) Emplacement of eo-Alpine high-pressure rocks in the Austroalpine Ötztal complex
(Texel group, Italy/Austria). Geodin Acta 14:345-360. https://doi. org/10.1016/S0985-3111(01)01072-5

Sölva H, Thöni M, Habler G (2003) Dating a single garnet crystal with very high $\mathrm{Sm} / \mathrm{Nd}$ ratios (Campo basement unit, Eastern Alps). Eur J Miner 15:35-42. https://doi.org/10.1127/0935-1221/2003/ 0001-0035

Sölva H, Grasemann B, Thöni M, Thiede RC, Habler G (2005) The Schneeberg normal fault zone: normal faulting associated with Cretaceous SE-directed extrusion in the Eastern Alps (Italy/Austria). Tectonophysics 401:143-166. https://doi.org/10.1016/j. tecto.2005.02.005

Spalla MI (1990) Polyphased deformation during uplifting of metamorphic rocks: the example of the deformational history of the Texel Gruppe (Central-Western Austroalpine Domain of the Italian Eastern Alps). Mem Soc Geol Ital 45:125-134

Spalla MI (1993) Microstructural control on the P-T path construction in metapelites from the Austroalpine crust (Texel Gruppe, Eastern Alps). Schweiz Miner Petro Mitt 73:259-275

Spiess R (1995) The Passeier-Jaufen Line: a tectonic boundary between Variscan and eo-Alpine Meran-Mauls basement. Schweiz Miner Petro Mitt 75:413-425

Spiess R, Marini M, Frank W, Marcolongo B, Cavazzini G (2001) The kinematics of the Southern Passeier fault: radiometric and petrographic constraints. Schweiz Miner Petro Mitt 81:197-212

Staub R (1924) Der Bau der Alpen. In: Beiträge zur Geologischen Karte der Schweiz, vol 52, Francke, Bern

Tessadri R (1981) Zur Metamorphose am Ostende des Schneeberger Zuges (Sterzing/Südtirol). In: Dissertation, University of Innsbruck

Thöni M (2002) Sm-Nd isotope systematics in garnet from different lithologies (Eastern Alps): age results, and an evaluation of potential problems for garnet $\mathrm{Sm}-\mathrm{Nd}$ chronometry. Chem Geol 185:255-281. https://doi.org/10.1016/S0009-2541(02)00419-9

Thöni M, Hoinkes G (1987) The Southern Ötztal Basement: Geochronological and Petrological Consequences of Eoalpine Metamorphic Overprinting. In: Flügel HW, Faupl P (eds) Geodynamics of the Eastern Alps. Deuticke, Vienna, pp 200-213

Thöni M, Jagoutz E (1993) Isotopic constraints for eo-Alpine high$\mathrm{P}$ metamorphism in the Austroalpine nappes of the Eastern Alps: bearing on Alpine olrogenesis. Schweiz Miner Petro Mitt 73:177-189

van Gool JAM, Kemme MMJ, Schreurs GMMF (1987) Structural investigation along an E-W cross-section in the southern Oetztal Alps. In: Flügel HW, Faupl P (eds) Geodynamics of the Eastern Alps. Deuticke, Vienna, pp 214-225

Viola G, Mancktelow NS, Seward D (2001) Late Oligocene- Neogene evolution of Europe-Adria collision: new structural and geochronological evidence from the Giudicarie fault system (Italian Eastern Alps). Tectonics 20:999-1020. https://doi.org/10.1029/ 2001TC900021

Zanchetta S (2010) The Texel-Schneeberg boundary in the Pfossen valley (Merano, NE Italy): geological-structural map and explanatory notes. Ital J Geosci 129:395-407. https://doi.org/10.3301/ IJG.2010.13

Zanchetta S, Poli S, Rubatto D, Zanchi A, Bove G (2013) Evidence for deep subduction of Austroalpine crust (Texel Complex, NE Italy). Rend Fis Acc Lincei 24:163-176. https://doi.org/10.1007/ s12210-013-0239-Z

Zanettin B (1971) Recent Geological Investigations in Southern TyrolAlto Adige, Eastern Alps. Verh Geol Bundesanst 1971:315-325

Zanettin B, Justin-Visentin E (1971) Considerazioni geologico-petrologiche sul "Tratto di Monteneve" ("Schneeberger Gesteinszug") (Alto Adige). Mem Ist Geol Miner Univ Padova 29:1-40

Zanettin B, Justin-Visentin E (1980) Il problema di Monteneve: messa a punto alla luce delle nuove conoscenze. Rendiconti Soc Ital Miner Petro 36:9-17 